Florida International University FIU Digital Commons

\title{
On Record: Soundscapes as Metaphor and Physical Manifestation of Memory in Early Holocaust Novels and Contemporary Criticism
}

Mariane Stanev

Florida International University, mstan001@fiu.edu

DOI: $10.25148 /$ etd.FI15032124

Follow this and additional works at: https://digitalcommons.fiu.edu/etd

Part of the English Language and Literature Commons, Ethnomusicology Commons, European Languages and Societies Commons, Jewish Studies Commons, Modern Literature Commons, and the Slavic Languages and Societies Commons

\section{Recommended Citation}

Stanev, Mariane, "On Record: Soundscapes as Metaphor and Physical Manifestation of Memory in Early Holocaust Novels and Contemporary Criticism" (2015). FIU Electronic Theses and Dissertations. 1907.

https://digitalcommons.fiu.edu/etd/1907 


\title{
FLORIDA INTERNATIONAL UNIVERSITY \\ Miami, Florida
}

ON RECORD: SOUNDSCAPES AS METAPHOR AND PHYSICAL

MANIFESTATION OF MEMORY IN EARLY HOLOCAUST NOVELS AND

CONTEMPORARY CRITICISM

\author{
A thesis submitted in partial fulfillment of the \\ requirements for the degree of \\ MASTER OF ARTS \\ in \\ ENGLISH \\ by \\ Mariane Stanev
}

2015 
To: Dean Michael R. Heithaus

College of Arts and Sciences

This thesis, written by Mariane Stanev, and entitled On Record: Soundscapes as Metaphor and Physical Manifestation of Memory in Early Holocaust Novels and Contemporary Criticism, having been approved in respect to style and intellectual content, is referred to you for judgment.

We have read this thesis and recommend that it be approved.

Ana M. Luszczynska

Asher Z. Milbauer

Michael P. Gillespie, Major Professor

Date of Defense: March 16, 2015

The thesis of Mariane Stanev is approved.

Dean Michael R. Heithaus College of Arts and Sciences

Dean Lakshmi N. Reddi University Graduate School

Florida International University, 2015 


\section{DEDICATION}

I dedicate this thesis to persons whose memories can only be known if our will to breach the faults of archived history surpasses the faults in our own aptitudes. I hope my writing can offer a fitting revenge for the offense of unmarked graves, scattered ashes, and lousy progenies. 


\section{ACKNOWLEDGMENTS}

The completion of this thesis would not have been possible without the academic, personal, and financial support of I received for the past two years. Professor Gillespie could not have been more helpful during the two long years of conceptualization, research, and writing of this thesis as my director. I must acknowledge Professors Luszczynska and Milbauer both in their capacity as my patient and knowledgeable thesis readers, but I must also acknowledge them in a different capacity: their help in getting me to graduate school in the first place. When I first met Profs. Milbauer and Luszczynska in the Fall of 2010, my ambition to go to graduate school was little more than an unlikely hope. That year, the two professors believed me when very few people would, and they helped me get here.

I also acknowledge the Writing and Rhetoric program for the teaching assistantship that supported me throughout the completion of this project. In the same avenue, I thank my parents' financial support that provided me with the material comfort for writing the thesis. I thank the friendly advice, energy, companionship, and so much more that I've received from faculty, friends and colleagues in the English department. Professors Nandini Dhar, Jason Pearl, and James Sutton were instrumental in assuring my success beyond the completion of this project. Equally instrumental are my wonderful friends and fellow DM balcony dwellers and Tuesday Club Comrades (graduate and undergraduate students in English and History here at FIU) David Frisch, Irene Inatty, Benjamin Rodrigues, Tiffany Fajardo, Michelle Alonso, Cayce Wicks, and Claudia Hernandez. As I continue on to my Ph.D. program, at a state still to be determined, I will never forget any of you. 


\begin{abstract}
OF THE THESIS
ON RECORD: SOUNDSCAPES AS METAPHOR AND PHYSICAL MANIFESTATION OF MEMORY IN EARLY HOLOCAUST NOVELS AND CONTEMPORARY CRITICISM
\end{abstract}

\author{
by \\ Mariane Stanev \\ Florida International University, 2015 \\ Miami, Florida \\ Professor Michael P. Gillespie, Major Professor
}

This thesis compares two perspectives on the production of Holocaust memory: a novel that leads up to The Holocaust in Britain and one that reflects the hindsight perspective of a liberator in the Soviet Union. The novels are Virginia Woolf's BETWEEN THE ACTS and Vasily Grossman's LIFE AND FATE. The analysis offers a locus of analysis for the diasporic literary energy created by the catastrophe in the $20^{\text {th }}$ and $21^{\text {st }}$ centuries. The project offers a theorized standpoint on the role of literature on official historical archives. Proposing a method through which contemporary readers can engage the diasporic event of The Holocaust, the project adopts both the extended metaphor and literal expression of soundscapes. Soundscapes encompass the immaterial processes of memorialization and the literal sonic textures developed in Holocaust novels. The critical perspective incorporates contemporary notions of narratology, archival practices, and cultural manifestations of language into the notion of literary ethnomusicology. 


\section{TABLE OF CONTENTS}

CHAPTER

PAGE

\section{Chapter 1:}

Before and After Catastrophe: The Questions Guiding the Contemporary Study of Early

Holocaust Novels.........................................................

Chapter 2:

Remembering Fragments: The Collapse of Traditional Storytelling and the

Dissemination of Memory in the Sonic Sphere................................. 33

Chapter 3:

In Excess of Materiality: The Soundscape of Death Camps as a Vehicle for Diasporic

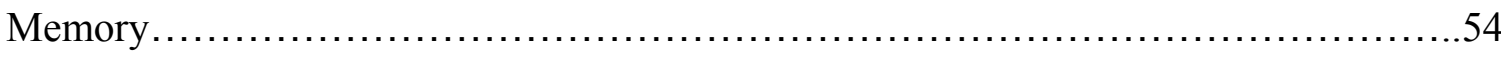

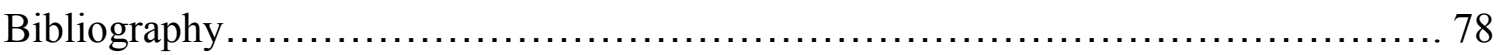




\section{Chapter 1}

Before and After Catastrophe: The Questions Guiding the Contemporary Study of Early Holocaust Novels

\section{The Project's Task}

This project will explore how early Holocaust novels reach backward and forward through time as they wrestle with their capacity to create a memory of the catastrophe for future generations. Its main premise is that analyzing the different processes of remembrance in the books helps us see the methodology through which these memories are conceived. Instead of proposing a definition of what early Holocaust novels sought to memorialize, the project will bring to light the contemporary gaze with which modern readers look back on these works. The goal is to offer a model through which modern readers can interact with contemporary notions of historical archive and literary perspectives on cultural memory, while still reading the books in their original context as

early Holocaust novels. Through an exploration of two such works, the project seeks to offer a point of departure for the diasporic tradition of literature that emerges from the need to create a memory of The Holocaust for newer generations who did not witness the catastrophe first hand. To facilitate the articulation of intangible nuances of remembrance, the project will employ the image of sonic textures and soundscapes as both a metaphor and literal expression of memory.

\section{The Spectrum and Literary Angle of Analysis}

When a book of fiction sets off to produce an account of the Holocaust, it must confront its own power of arbitration over historical production. Without the exercise of self-criticism, fiction that seeks to preserve or create the memory of historical catastrophe 
can suggest an authoritative version of events that does not acknowledge its own power of narrative construction. In the case of novels, where the author must interact with a genre that has its own internal history of power relations and political circumscription, the level of self-awareness needs to be even higher. ${ }^{1}$ The responsibility of production ascribed to the author is also present in the domain of criticism. When novels produced about the Holocaust are read from an informed theoretical background, self-awareness can become over-zealousness and rapidly transform the fiction into a literary soapbox for the critic in favor of or against the author.

To balance social responsibility, critical awareness (of genre, critical theory, economics, etc.) and the novel's reputation as entertainment literature, authors of Holocaust novels must make conscious choices of genre-format, narrative style, content selection, and critical positioning. By the same token, the critical lens of the project will position itself at a seminal moment of the production of Holocaust memory to analyze the mechanisms through which two authors sought to express their historical perspective on the Holocaust. Both novels will be read as projects that seek to archive the Holocaust as an event of human history without erasing the personal stories of actual historical

\footnotetext{
${ }^{1}$ It is important to establish the economic history of the novel as a dominant form of literary representation. Walter Benjamin likens the rise of the novel to the erasure of storytelling, a theme that will be taken up again in Chapter 2: "The earliest symptom of a process whose end is the decline of storytelling is the rise of the novel at the beginning of modern times... The dissemination of the novel became possible only with the invention of printing" (79). The novel is irrevocably inserted in the history of capitalist production. Contemporary novelists cannot extricate their acts of storytelling from the history of capital mechanization and commoditization of the novel as a genre. In terms of Holocaust novels, the history of power is an even more delicate matter because the power relationship is not measured in capital amounts, but in the loss of individual stories and nuanced memories of history.
} 
individuals who endured the catastrophe. ${ }^{2}$ This project brings together two novels written at crucial moments of Holocaust literature: one composed in 1941 in expectancy of the Holocaust, envisioning the memory of an event that was yet to come, and the other created in retrospect of the Holocaust, in full awareness of the historical event, and in full thrust of the diasporic energy caused by it.

This project brings together novels written by Virginia Woolf and Vasily Grossman. They formulated characters that express the most intimate experience of humanity in a situation of war, while at the same time, the characters provide a version of public storytelling that furnishes future generations with a historical account of The Holocaust. Woolf's character, Miss La Trobe, from Between the Acts, works within the social expectation of the pre-war years in the English countryside while Grossman's character, Sofya Levinton from Life and Fate, works within the reality of combat in Russia's Western Front. In Between the Acts, Woolf presents the role of art in waranxious Britain by contrasting traditional methods of storytelling with contemporary material conditions that will require a re-conception of art while in Life and Fate, Grossman coordinates the post-war recovery of national identity without committing to the expedient of historical revisionism favored by the Stalinistic brand of Social Realism. Bringing them together offers contemporary criticism a point of departure in the archiving of The Holocaust.

2 The word "archive" must be understood in the sense of making the Holocaust part of the official state memory. Though the contemporary notion of archiving has moved away from a strictly textual approach, the notion of official and unofficial archiving as it pertains to this project must be attributed to Jacues Derrida's seminal Archive Fever: A Freudian Impression. In Derrida's work, he explores the Freudian take on archive as internal inscription of memory. However, the term "archive" or "archive fever" has become synonymous with the study of practices of production of memory. 
Both books offer moments where the act of memorialization, or the act of making a memory of the events of 1941 is fictionalized. The two subsequent chapters will analyze these moments so that, read against one another, they offer a theorization of the point of departure of Holocaust fiction in the following 70 years. In Woolf's book, the act of storytelling is fictionalized through a pageant representing the history of the British Empire that runs through the body of Between the Acts. In Grossman's, since he writes in retrospect of the events, Sofya's internal monologue is full of moments of reflection on how people will remember her fate in the future, framing her own memory in the processes that created it. My analysis will ground itself on the fragmentation of sound in Between the Acts and in the use of music in the camps in Life and Fate as both an analogy for the creation of memory and as a literal act of reflection of Grossman on his own narrative.

Sound will be a crucial element to the analysis. In both the pageant and the musical element of the camps, sound composes a background of literary energy that converges in the creation of a sonic texture for the books. That texture can be analyzed for its role in creating a palpable sense of past and future converging on the memory of The Holocaust. The analysis of literary soundscapes, rapidly becoming known as literary ethnomusicology, theorizes the unseen and immaterial presence of trauma that manifests itself through linguistic rhythms, plot stylizations, material objects as sonic imagery, and ritualization of everyday lives expressed in literature. ${ }^{3}$ Body, spaces, and memory

\footnotetext{
${ }^{3}$ In his 2014 article "Literary Ethnomusicology and the Soundscape of Jean Toomer's Cane," Daniel Barlow defines literary ethnomusicology as "the practice of participant observation and interpretation of musical cultures... in the form of a literary, aesthetically innovative, yet also partly empirical account of agents making music, living with music,
} 
become part of a soundscape running through the text in a way that defies the materiality of traditional archives. Since sound is both physical and disembodied, and because it propagates both linearly (from an origin to a listener, or until it dissipates unheard) and in reverberations, echoes, and pliable waves that propagate in all directions and have the power to escape the intentions of its point of origin, it is a perfect metaphor for memory.

\section{This Project's Understanding of What Is a Holocaust Novel}

To classify a book as a Holocaust novel is to speak both of its form of storytelling and of its historical content. To explain this project's definition of the Holocaust novel, it is necessary to define what it means to narrate a story as a novel, and what it means to speak of the historical event of The Holocaust. The definition does not seek to decipher the complexities of the history of the novel as a genre or all of the historiographical nuances of articulating history on literary record. To provide an operating definition of the concept, the scope of the word "novel" must be limited to its conventions on character perspective, and the definition of Holocaust literature to be contained to literature that evokes The Holocaust for a contemporary reader.

Novels are often associated with their use of strong individual characters as an expression of the human mind. Historians of the novel as a genre often link the use of a single human mind as perspective as one of the definitive shifts in literature that gave rise

and expressing cultural values through music" (193). Another 2014 publication, Write in Tune: Contemporary Music in Fiction, edited by Erich Hertz and Jeffrey Roessner, establishes the need for further study in ethnomusicology as a tool for literary analysis. This argument joins the contemporary dialogue while adding a phenomenological and political dimension to the use of soundscapes in literary analysis and also taking the conversation beyond the necessity to work exclusively with texts that feature music as a main component of the narrative. Instead of a trope or theme, this arguments expands the study of soundscapes in literature as a literary technique. 
to the novel in the $18^{\text {th }}$ century. ${ }^{4}$ For instance, in his The One Vs. the Many: Minor

Characters and the Space of the Protagonist in the Novel, Alex Wolloch engages the notion of the "rise of character" as a characteristic of the novel as a genre:

For a ling time now, characterization has been the bete noire of narratology, provoking either cursory dismissal, lingering uncertainty, or vociferous argument....Focusing on the character-system-and the character-spaces that it encompasses and puts into relation-highlights the way that the "human aspect" of a character is often dynamically integrated into, and sometimes absorbed by, the narrative structure as a whole (1415).

For this project, the singular perspective of a human mind is the first requirement for a book to be defined as a Holocaust novel. Since what is at stake with Holocaust novels is the act of memorialization or archiving of the historical event, it is important that singular experiences compose the public record as opposed to a general understanding of history that obfuscates private experience. Though the classification of Between the Acts and Life and Fate as Holocaust novels will be the subject of their own individual analysis chapters (Chapters 2 and 3), it is necessary to offer an overview of the books' characteristics as such.

\footnotetext{
4 Though strong characters are a crucial element of this project's definition of novels, it is important to acknowledge the challenges to the current understanding of the rise of the novel. Relevant work in the field of novel history is shifting the perspective from an Eurocentric rise of the novel to a more comprehensive global phenomenon. For instance, instead of focusing on the rise of the character, Srivinas Aravamudan's 2012 Enlightenment Orientalism: Resisting the Rise of the Novel provides a model that recasts the public imaginative encounters of East and West in the 18th century as the catalyst for the rise of the novel as a genre.
} 
When it comes to historical content, this project's definition of Holocaust novels is a direct reference to their ability to create memories. As Holocaust novels must emphasize the personal experience of catastrophe to create memories that go beyond historical generalizations, the second foundational element of what this project considers a Holocaust novel is the book's capacity to memorialize the event without needing to limit its scope exclusively to the material reality of the tragedy. A Holocaust novel must incite the memorialization of the Holocaust in their readers' minds, but that does not necessarily mean to speak directly of the catastrophe. The capacity to visit more than exclusively the camps, the ghettoes, or the massacre sites in cities and villages throughout the European continent is necessary because it bears into account that the lives of survivors and witnesses encompassed more than their experience of The Holocaust. ${ }^{5} \mathrm{~A}$ Holocaust novel must be able to understand the human mind as more than the sum of its immediate experiences. That is not to say that a book that speaks exclusively of the material realities of The Holocaust, such as Primo Levi's If This Is a Man, is a lesser work of memorialization for the catastrophe. Works such as Levi's are crucial in their own right because they create a first person sensory account of The Holocaust that belongs to its own category in the study of Holocaust literature.

${ }^{5}$ An example from pop culture, Hal Ashby's 1971 Harold and Maude, illuminates the power of memorializing The Holocaust without limiting the storytelling perspective to the material realities of the catastrophe. In the film, Maude lifts Harold out of a depressive stupor with her eccentric and sometimes lewd passion for life. Around $3 / 4$ of the way through the movie, in a shot that lasts less than 5 seconds, the camera lowers to show Maude's Auschwitz tattoo. Without as much as a mention of The Holocaust, the movie memorializes the catastrophe through the singular fictional expression of a human mind. 
Between the Acts is a Holocaust novel both because of textural elements created by Woolf in the text of the book and because of the knowledge contemporary readers bring to their experience of the book. The tension of impending doom Woolf captures in the novel would not be enough to characterize it as a Holocaust novel since the angst that pervades the narrative could be attributed to a simple fear of death or apprehension for the fate of European civilization. However, in one of the highest moments of tension in the book, a question rings out: "What about the Jews? People like us"? (104). Woolf's personal connection with the Jewish community, which will also be discussed later in this chapter, helps to explain the presence of the question in the first place, however, the presence of the question is also not enough to call the book a Holocaust novel. It is only when the question is read by contemporary readers that the fear for the unknown is transformed into an invocation of the known catastrophe. Modern readers know the answer to the question "What about the Jews?" in context of WWII, and so the book becomes a Holocaust novel.

Life and Fate's classification as Holocaust literature is clear for readers familiar with the text's chapters in which the camps are materially described, and Sofya Levinton's execution in a gas chamber is narrated in detail. However, it is necessary to speak on its classification as a Holocaust novel as it is understood by this project. The complexity of Sofya Levinton's mind offers a view into the material events of the material conditions of The Holocaust without being constricted by its immediacy. Sofya's richness as a character who interacts with her surroundings in the train compartment, the camp, and then in the chamber, offers an honest look into the highly private thoughts that comingle with a person's greater sense of public belonging as she is confronted with her 
death. Sofya's capacity of seeing beyond the immediacy of her capture, transportation, and execution, make Life and Fate truly a Holocaust novel.

\section{The Idea of Private vs. Public Memory}

The single human perspective works side by side with the notion of soundscapes: a single human mind must be heard so that it can resonate beyond its own experience. Woolf and Grossman's narratives of the Holocaust offer memories of the event that operate within the metaphor of sound. They operate from the most primal characteristic of witnessing: the urge to speak the truth about an event and the knowledge that truth is immediately dispersed through space and time when it is uttered. The understanding of these characters will set up a literary discussion of sonic memory in Chapters 2 and 3.

Woolf and Grossman chose to ground their narratives on strong characters because they understood that a single character can manifest humanity as it becomes known to the audience. Woolf created Miss La Trobe, an artist whose performance piece drives the plot of Between the Acts. Miss La Trobe embodies the difficulty in producing work of artistic integrity when the artist's private interests and the urge to please an audience overwhelm the necessity for to produce art that invokes the material realities of its time. Vasily Grossman created Sofya Levington, a Jewish Red Army doctor whose arrest, transportation, and execution in a Nazi death camp are portrayed chronologically, but in non-continuous chapters of Life and Fate. Her internal dialogue and her interaction with other characters embody the difficulty in creating art that accurately portrays a single human life while attempting to narrate the fate of an entire people. 


\section{The Intersection of Woolf and Grossman}

The connection of Between the Acts and Life and Fate being established as early Holocaust novels, it is now necessary to cover the social and historical trajectories of the two books' creations. To set up their literary analyses in Chapters 2 and 3, this chapter will outline how Woolf and Grossman's perspectives as authors compliment each other, and it will delineate their individual attitudes toward literary creation and how they intersect. The chronological and ideological ground from which the two texts emerge will be defined as urgency in creating memory as a response to a heightened sense of mortality, the acknowledgment of the human body in war, and the literary invention necessary to comport the creation of a public memory of catastrophe in modern literature. Woolf and Grossman's break with European tradition, their choice in not becoming rhetoricians of the State, their rhetorical counter-attacks to fascism, and the uniqueness of their literary female perspectives will formulate the personal connection between the authors.

\section{European History as Context}

To demonstrate the extent to which Woolf and Grossman were caught in a deep cultural reconfiguration of absolute meaning, the 20th century must be understood against the backdrop of social transformations that can be traced to the Enlightenment. The modern European idea of national identity inasmuch as it is relevant to moments of crisis can be traced to the Enlightenment. Eric Hobsbawm in Age of Revolution, remarks that when people began to cover greater physical distances because of improvements in 
technology in the late 16th century, the world became smaller, not bigger. ${ }^{6}$ Absolute ideas of good, evil, and nationhood accompanied that movement of solidification of scattered peoples into nations. Since a few of those nations expanded into empires, the rhetoric that held them together had to be strong enough to hold such a large number of people under the same narrative. Ironically, it was the force with which the national identity of nationhood held people together that initiated its gradual crumbling. Essentially, nuance eroded the broad strokes of national identity. It is possible to observe popular movements chipping away at the absolute ideas of nationhood, truth, good, and evil with every revolution - the act of eroding established truth - in Europe since the Enlightenment. In the 20th century with two consecutive World Wars, the national expression of national identity could not be held together anymore.

Woolf and Grossman were individuals who felt the need to make sense of the chaos of war and to overlap their own notions of literary sense with these of their own societies. After WWII, what societies meant by "sense" could no longer be relied upon as traditional stepping-stones for literary signification. There was no stable point of departure to organize their artistic accounts of war. Both Woolf and Grossman were writing in an environment of collapsed of institutions that had offered a definitive starting place for the narratives of war in the past. When the idea of nationhood crumbled under its own weight, nationally sanctioned identity via propaganda is an attempt to reverse the tide of history by forcing a strong nationalistic feeling onto large populations via artistic manipulation.

${ }^{6}$ Hobsbawm's direct quote is "Yet, if the world is in many respects smaller, the sheer difficulty or uncertainty of communications made it in practice much vaster than it is today" (8). 


\section{Background on Woolf and Grossman}

Woolf was an insider-outsider in her society. She descended from families always on the fringe of nobility, the lower upper classes. She was a notorious critic and novelist, but she could not get a university education. She was capable of being well spoken and charming, but something always seemed to keep her from enjoying the company of people around her. She was married, but she was gay. In a diary entry from the time when she started writing Between the Acts, it is possible to see how Woolf seemed resolute to emphasize her outsider perspective on the new manuscript:

I do my best work and feel most braced with my back against the wall. It's an odd feeling though, writing against the current: difficult entirely to disregard the current. Yet of course I shall. And it remains to be seen if there's anything in P.H. [Pointz Hall, working title for Between the Acts]. In any case I have my critical brain to fall back on. (308)

When WWII broke out, Woolf's sense of being isolated and simultaneously inseparable from a public community became more apparent. The isolation and communal sense of fear are evidenced in her diary on April 15th, 1939:

What's odd ... is the severance that war seems to bring: everything becomes meaningless: can't plan: then there comes too the community feeling: All England thinking the same thing — this horror of war-at the same moment. Never felt it so strong before. Then the lull and one lapses again into private separation. But I must order macaroni from London (WD, 313).

Woolf wanted to represent the human experience while accounting for the mystery of literature, social relevance, and her unique perspective as an insider-outsider. 
Woolf did not have a strong religious identity, but she married Leonard, a Jewish man. As Oliver Lubrich tells in his Travels in the Reich, 1933-1945: Foreign Authors Report from Germany, the couple travelled through Nazi Germany in 1935 and the journey exposed the couple to the social policies of the regime at the time. Woolf wrote in her diary of an incident at the German customs where Leonard's pet marmoset Mitzi seems to have diffused the animosity of the officers:

Sitting in the sun outside the German customs. A car with the swastika on the back window has just passed through the barrier into Germany. L. is in the customs...Ought I to go in \& see what is happening? The Dutch Customs took 10 seconds. This has taken 10 minutes already. The windows are barred. Here they come out \& the grim man laughed at Mitz...We become obsequious - delighted that is when the officers smile at Mitzi (73-74).

A few years later, the bleakness of the fate of the Jewish people in Nazi Germany Woolf experienced on the trip would become part of their own reality. While Woolf wrote Between the Acts, Leonard Woolf purchased and stored cans of petrol so that he and his wife could commit suicide by asphyxiation with car fumes in case of a Nazi ground invasion. ${ }^{7}$ While the Woolfs made the suicide agreement and chose its method, the first prisoners of the Nazis were also executed by gassing in the year of 1941. But the executions did not yet employ the insecticide Zyklon-B, which would be the agent of mass extermination in the years to come. The gas agent first employed by the Nazis was CO fumes from car exhausts. Unknowingly, trying to escape the fate Nazi rhetoric and propaganda had created for the Jewish body, the Woolfs nearly fulfilled it. The Woolfs'

${ }^{7}$ The Unknown Virginia Woolf, page 230. 
near suicide reinforces the idea that the relationship between private action and public order in war happens in a completely different dimension.

Woolf's experiences during the war dictated much of her choice in literary subjects in her later years. However, the artistic and philosophical aspect of writing was still a major aspect of Woolf's writing even though her attention was on non-fiction. The textual awareness of her craftsmanship with words is what makes her such a unique writer of fiction dealing with catastrophe and memory. The pre-war environment in England affected Woolf's writing in that her literary criticism took a sharper turn to concerns with the validity of literature for the modern world. The ability to use words artistically while acknowledging the unpredictable nature of artistic communication was something Woolf struggled with openly. In a broadcast to the BBC in 1937, Woolf touches on the crux of the matter of representing the human experience in literature. ${ }^{8}$ In discussing the power of words to express new sensations as we encounter them, she says, "Word is not a single and separate entity...Words belong to each other... and only a great poet knows that the word incarnadine belongs to multitudinous seas" (DotM, 203). ${ }^{9}$

"Incarnadine" can be traced to the Latin "incarnate" or "incarnatus," which means not only "made of flesh" but also is the past participle of "incarnare," or "to embody" $(O E D)$. Incarnadine means to be embodied. Incarnadine carries within its composition an

${ }^{8}$ Fragments of the recording survived technological limitations and Nazi air raids in London to provide us with a few minutes of Woolf's recorded voice.

${ }^{9}$ The word combination is used by Macbeth as an image for his irredeemable guilt: What hands are here? Hah! They pluck out mine eyes.

Will all great Neptune's ocean wash this blood Clean from my hand? No; this my hand will rather The multitudinous seas incarnadine, Making the green one red. (2.2.54-60) 
embodiment that is prior to its utterance, or its state as a word as opposed to being flesh. That embodiment, always in the past tense, is constitutional to the mysterious force, revealed only to great poets, that makes it belong to multitudinous seas. Woolf's personal connection with the Jewish community—regardless of Leonard's personal faith-, coupled with her open willingness to break with tradition for the sake of literary authenticity, give her enormous power as an author of Holocaust novel.

Grossman, also an insider-outsider in his society, was already a well-known novelist and essayist before the war, and his journalistic work from the front made him a household name in Soviet Russia. Even though he was well known, most of Grossman's work was considered subversive and dangerous by the Writer's Union, which was effectively a self-policing censorship agency for Stalin's government. The simultaneous fame and infamy he enjoyed among high Communist Party officials reflects his position in the Red Army during the war. As a Jewish man, he was an outsider, and as a wellknown writer, he had insider access to the highest offices of command. Since he could not occupy either position in full, he could never surrender his individual judgment to what John Garrard calls the "Procrustean bed"- of national identity in war representation.

As a Jewish man, he could not ignore his first-hand witnessing of Hitler's "Final Solution" and the anti-Semitism within the Red Army. Grossman believed it was the job of journalists and novelists in the post war period to combat the historical revisionism proposed by the Soviet State and portray the extent of the Jewish Holocaust. As an experienced writer and careful rhetorician, he knew that simply stating the truth in numbers and factual events was not enough to combat the State-sponsored rhetoric. Grossman believed individual accounts of the war were the most powerful tools with 
which to communicate the truth pertaining to a particular situation in literary representation.

In addition to the Russian context of his literary roots, Grossman also embraced the role that has pertained to artists since Aristotle: the act of providing meaning to war without mindlessly justifying armed conflict. ${ }^{10}$ Katerina Clark, a contemporary critic who takes a close look at Grossman's role as a war journalist, highlights the philosophical components of his fiction, “... Grossman also sought to frame his account of the war in terms of the great movements in history and the philosophical issues they raise" (609). The big picture and the philosophical concerns Clark references form the groundwork of what would become his methodology in memorializing The Holocaust.

Grossman understood himself as the inheritor of the Tolstoyan tradition of Russian literature in which novels function as the art of self-reflection and moral criticism. To understand Grossman's intentions with Sofya's story, Life and Fate must be understood as a historically charged project, as John Garrard, a major contemporary Grossman scholar remarks in his Humanistic reading of Life and Fate:

A few Russian writers (as opposed to Soviet writers) refused to serve the state and follow the dictates of Socialist Realism. They sought instead to remain true to the best traditions of 19th-century Russian literature, to "mingle profit

\footnotetext{
10 In the Nicomachean Ethics, Aristotle defines "art" as the action employed in attaining "the end" of a particular good, or something which is desired.-To him, there must be something "which we desire for its own sake" that gives collective meaning to the individual ends we pursue. He calls that something "the chief good." The word "good" in this context does not mean righteous or pleasurable, as the chief good can be any notion that provides meaning to all other actions.
} 
with pleasure" by delighting the reader and instructing him in equal measure.

Grossman's unique relationship with tradition assured the breadth of his own role as the creator of Holocaust memory.

\section{The Material Realities of the Books within their Societies}

Life and Fate and Between the Acts are connected by chronology as the first is set in 1941 and the second was published that year. 1941 is of historical significance because it marked the beginning of the most intense period of WWII and especially of the Holocaust. It also is the year of the Massacre of Babi Yar-, the first gassing in Auschwitz, the Battle of Stalingrad, and it was the last year of The Blitz- ${ }^{11}$ Because both authors were sensitive to the necessity of accounting for individual human experience in war, the books encompass the events of 1941 while preserving the uniqueness of individual experience. A brief look at how the contexts of the books affected their public reception helps to conceptualize their initial space within a public notion of The Holocaust.

After Joseph Stalin's death, Grossman attempted to publish Life and Fate as his strongest attack against the revisionist memory of WWII forwarded by Stalin's government. Grossman believed that with the death of Stalin, the Soviet public was ready for a sober analysis of the battle of Stalingrad, the rise of Stalinism, and the role of their own country played on the persecution of Jews in WWII Europe, which are the main plot

\footnotetext{
${ }^{11}$ During the massacre of Babi Yar, the Jewish population of German occupied Kiev was told to appear at a ravine for deportation, and subsequently, 33,771 Jewish people were executed by machine gun and buried in a single mass grave. Meanwhile in England, Woolf wrote Between the Acts through the two years of German bombing of civilian targets in London.
} 
components of the novel. However, his optimism in Khrushchev's- political deStalinization proved to be miscalculated. ${ }^{12}$ In 1961, following the attempt at publication, government forces seized Life and Fate along with the ribbons of Grossman's typewriter, legally "arresting" the book, but not its author. Grossman died 3 years later believing all copies of the manuscript were lost. Gladly, he was wrong, and the manuscript was smuggled to the West in 1974.

It is apparent from the book's nuanced understanding of humanity in war that he was seeking much more than to assign blame to the perpetrators and bystanders of The Holocaust. Life and Fate is almost 900 pages long and has 157 named characters who can be divided into 15 groups of intersecting story lines. Since of the complex web of human activity, it is almost impossible to blame any character for their individual shortcomings. Most of their hardships — as well as their joys — are caused by another's behavior. By the same token, it is impossible to absolve anyone of individual guilt. Fate, in the novel, takes on the meaning of people doing things for their own reasons, and those actions affecting other persons for completely different and unforeseen reasons. Therefore, fate is indeterminate but caused by human beings.

Grossman uses the intersecting plot lines so that even if a character's actions are not explained by another's, they are illuminated by them. For instance, Victor Shtrum's wife, Lyudmila Shaposhnikova, refuses to allow her mother in law, Anna Semyonovna, to move in with her family, directly causing Anna's death. ${ }^{13}$ Grossman narrates Lyudmila's

\footnotetext{
${ }^{12}$ Khrushchev was Stalin's successor. He instituted policies which slackened his predecessor's standards of censorship for literature.
} 
decision to deny her mother in law shelter as an episode in a family's relationships, as opposed to an isolated event. For that reason, the reader is left with a sense that it is impossible to judge her decision as a single isolated act against her mother in law, but a chapter in a family's life. Lyudmila's life also intersects with Sofya's, as she is friends with Lyudmilla's sister. 150 pages after Sofya's death, Grossman uses Lyudmilla once again to provide individual complexity to public tragedy when her conversation with her sister provides us with the last mention of Sofya's name on the story: “I I haven't heard any news of Sofya Osipovna. She seems to have vanished into thin air,' said Yevgenia. 'The Levinton woman?' 'Yes, of course.' 'I never did like her... Are you doing any drawing?"' (675). The exchange reinforces Grossman's portrayal of Sofya's death as the death of a single human being, as we gain perspective on how her disappearance affects some of those who knew her.

While Grossman battled public opposition to his book's publication, Woolf battled the interiorized daemons of a lifetime of witnessing war and destruction. Rather than a public foe, what makes the material reality of Between the Acts' publication is Woolf's suicide upon completion of the novel. Without attempting to decipher Woolf's own private decision to end her life, it is possible to speak of the artistic exhaustion that seems to have marked the final stages of production of Between the Acts. A manuscript that seems to have started from the urge of freeing her art from the looming sensation of war, became the textured embodiment of the material conditions Woolf sought to drive away.

13 Viktor and his mother are Jewish, and Victor's wife is not. Viktor's mother dies in a Jewish ghetto. 
As it is the case with Grossman's work, Between the Acts also uses the intersection of individual lives as an expression of intersecting private and public ends. While Grossman accomplishes the effect by having characters influence each others' lives, Woolf does so by merging the characters' voices into the narrative voice of the book. The characters are simultaneously afraid of connecting to other persons, and are intrinsically connected to them. The narrative voice seems to emerge from their intertwined perceptions, emotions and collapsed dialogue of audience members and artists. The narrator is a chorus and a singular voice at the same time emphasizing the intertwined sense of public memory in post-catastrophe literature. ${ }^{14}$

The theoretical and socio-cultural concerns of Woolf's last decade are expressed in the different perspectives from which the reader witnesses the act of artistic communication. Woolf provides a detailed account not only of Miss La Trobe's mind, without ever narrating it through traditional literary devices, but she also gives equal attention to the inner lives of the audience members and Miss La Trobe's expectations of her performance. Mr. Dodge for instance, saw “ ... parts without a whole; he [was] amused by the peculiarity of arms, colors, and movement; "he clapped until his palms

${ }^{14}$ Melba Cuddy-Keane describes this incomplete togetherness as an innovation by Woolf on the traditional Chorus of tragedy. She suggests that looking at the cacophony of character codependency as a tragic chorus (society from which tragic hero emerges) transplanted into a radically different comedic mode is a good way of understanding how these characters work in tandem so as to suggest an evolving, pulsating picture of individual characters in contrast to their environment:

In creating a distinctive choric voice, Between the Acts both returns to the ancient choral band and creates a comic mode. The new collective voice emerges through a subtle manipulation and transformation of [traditional comic modes]. Woolf inhibits her satiric impulse by modifying the satire with elements of amiable comedy and expands the amiable comedy with elements of liminality to create a subversive revolutionary mode, the art of the whole community. (276) 
stung” (93), while Etty Springett remarked “'Cheap and nasty, I call it' referring to the play, and shot a vicious glance at Dogdge's green trousers, yellow spotted tie, and unbuttoned waistcoat"(173). The audience members of Between the Acts functions as an expression of the public sphere of memory and how any individual sensations can truly define the collective experience of history.

For that reason, when Miss La Trobe calls herself "a slave to her audience" (95), referring to her inability to produce art according to her vision, the reader knows that her concern does not acknowledge the complexity of opinions contained in the members of her audience. Miss La Trobe is sacrificing her vision for an audience whose demands she has imagined herself. Since Woolf forces us to confront who is Miss La Trobe's audience, we are forced to question if Miss La Trobe is not in fact writing to an audience of her own creation — an audience that is composed of her own material anxieties as an artist, and creator of public memory.

\section{Pain as Limit and Possibility}

Any analysis of Holocaust literature, even within the concept of Holocaust novels, must offer a theorization of the place of the human body's destruction in literature. Neither author experienced the physical horror of The Holocaust. However, both their books carry a palpable sense that the human body as literary archive, must tell the story of such horror. Looking at the experiences Woolf and Grossman had with the notions of human flesh helps to articulate the physical element of catastrophe in their works.

Woolf and Grossman would not have been able to create an accurate expression of humanity without accounting for the physical violence the human body endures in war. Pain, unlike the awareness of death, does not alternate between private and public 
consciousness. Pain is utterly personal. As Alexander Solzhenitsyn said, "How can you expect a man who's warm to understand a man who's cold?". ${ }^{15}$ The same applies to how the representation of a person inside of a gas chamber can be communicated (as in having one's memory shared through literary representation) to a person outside of the chamber, and how an author who is contemplating the end of her civilization can relate that anxiety to her audience. Pain is experienced in the present tense, while rhetoric and art always work either looking back, or forward. For that reason, extreme physical violence and the fear of immediate death return to our critical sense the fact that there may be elements of humanity which cannot be shared even by the best art.

Elaine Scarry captures the theoretical effects of pain on language in her Body in Pain: "Physical pain does not simply resist language but actively destroys it, bringing about an immediate reversion to a state anterior to language, to the sounds and cries a human being makes before language is learned" (4). Scarry's insight at first seems to place the most intimate experience of the human body in war beyond the reach of Woolf and Grossman. In fact, realizing that pain and text are theoretically incompatible opens the doors to a much more nuanced critical perspective on the representation of physical humanity in war. Husserlian aesthetics along with Scarry's insight can be taken into consideration without precluding the authors' representation of the human body in war. ${ }^{16}$

\section{${ }^{15}$ One Day in the Life of Ivan Denisovich, p. 23}

16 The body is essentially an epoche, a phenomenon which is suspended from all knowable judgment and is taken as a starting point of all doubt in cognitive reasoning, as opposed to being judged by an observer according to his or her previous understanding. To Edmund Husserl, the means through which consciousness relates to the epoche is the ultimate question of phenomenology. For him, there is "but one possible method [of knowing], the one demanded by the essence of intentionality and of its horizons" 
Woolf and Grossman were not phenomenologists. However, because of their personal experiences with the human body, and the literary standards they set for themselves, they were also implicated in the quest to express the epoche in as direct as possible connection with consciousness when it comes to the human body in pain. Their personal experiences are manifested in their writing style. That manifestation radically influenced their accounts of Miss La Trobe and Sofya Levinton. Both have bodies which are palpable in their narrative composition, but neither Woolf nor Grossman reveal their bodies in a traditional form. There is no lengthy physical description for either in the respective books. Nevertheless, when Miss La Trobe experiences the physical crisis of artistic failure, and when Sofya Levinton is killed, their bodies come through in representation. Each instance will be discussed in full in Chapters 2 and 3. However, Woolf and Grossman's notions of physicality must be presented in the context of their overlapping perspectives of war representation.

Woolf had an intense relationship with her body which she characterized as a mix of shame and delight. In "A Sketch of the Past" Woolf writes:

...my natural love for beauty was checked by some ancestral dread. ...Yet this did not prevent me from feeling ecstasies and raptures spontaneously and intensely without any shame or the least sense of guilt, so long as they were disconnected with my own body. I thus detect [an] element in the shame

(Cartesian Meditations, 64). Intentionality is one of the most complex terms in Husserl's phenomenology, but Levinas expresses it in sufficiently narrow terms for this context. For him, Husserlian intentionality is "the fact that all consciousness is not only consciousness but also consciousness of something, i.e., related to an object" (37).

Epoche, therefore, are intended in a function of knowing, and thus become cognitions. It is in this cognition that the artist can hope to make the human body an integral part of the picture of humanity at war. 
which I had in being caught looking at myself in the glass in the [Talland

House] hall. I must have been ashamed or afraid of my own body (68-9).

Woolf continues the passage by recounting the sexual abuse she suffered from her half brother. ${ }^{17}$ The reasons for Woolf's dread and joy with her physical body may have a distinct root in the fact that she was sexually assaulted. However, it is not necessary to determine why Woolf had a relationship with her body that involved dread and jubilation To determine that the feeling affected her literary attitude toward the bodies of her characters. The attitude does not explain the lack of lengthy physical descriptions for Miss La Trobe's body, but it adds a layer of complexity to Woolf's question.

Scholars have given Woolf's physical illnesses literary meaning. ${ }^{18}$ However, it is important to remember that Woolf enjoyed periods of good health that were as important to her identity as were her periods of illness. She was a typesetter, seamstress, and packager for Hoggarth Press, where she worked in an under-heated basement with broken windows, poorly functioning toilet, and very little professional help, ${ }^{19}$ and she would

${ }^{17}$ Another memory, also in the hall, may help or explain this... Gerald Duckworth lifted onto [a slab for dishes on the dining hall] and began to explore my body.... stiffened and wriggled as his hand approached my private parts....I remember resenting, disliking it... This seems to show a feeling about certain parts of the body... how they must not be touched... It proves that Virginia Stephen ... was born many thousands of years ago; and had from the very first $t$ encounter instincts already acquired by thousands of ancestors in the past $(M o B, 69)$.

${ }^{18}$ David Wanczyk uses her "fidgets" as a characterization for her literary style in " "So They Fidgeted': The Modernist Twitch of Between the Acts."

19 In “'Opening the Door': The Hoggarth Press as Virginia Woolf's Outsider's Society," Ursula McTaggart describes the staff's opinion of Woolf's work style: "John Lehman recalls Woolf working beside employees in overalls, as Robert Kennedy, a clerk at the Press, notes that 'Mrs. Woolf is a pretty fast worker considering she's not a professional" (66-7). 
participate in animated play with her nieces and nephews regularly. ${ }^{20}$ Bodies do not feature prominently in her earlier fiction, perhaps with the exception of Septimus Smith's struggle with PTSD in Mrs. Dalloway. ${ }^{21}$ But in Between the Acts, the physicality of characters, nature, and architecture is present in the state of Poyntz Hall (the house where the action occurs), the costumes in the pageant, and as Chapter 2 will discuss in detail, the physicality of Miss LaTrobe herself.

Grossman had by all accounts a comfortable physical existence before the $\operatorname{war}^{22}$. When he first enlisted, he was pudgy, and his superiors feared his soft physique would mean he could not report directly from the front. Within weeks, however, Grossman had learned how to shoot a pistol, and had dropped considerable weight ${ }^{23}$. His body transformed as his experience of the bodies of others changed around him. As a trained

${ }^{20}$ John Lehman explores Woolf's relationship with her nephews and nieces in Woolf and Her World:

Clive Bell has written that they [his children] enjoyed beyond anything a visit from Virginia, and looked forward to it as the greatest treat imaginable. 'Virginia is coming, what fun we shall have!'... Nevertheless she could write in her diary, after one of these parties, in December 1927, '... I don't like the physicalness of having children of one's own.... I can dramatise myself as a parent, it is true. And perhaps I have killed the feeling instinctively; or perhaps nature does' (70-1).

${ }^{21}$ Woolf's 1925 novel featured Septimus Smith, a war veteran whose gradual descent into madness.

${ }^{22} \mathrm{He}$ was misdiagnosed as "chronically tubercular" while working at a mine as a chemist, and took full advantage of the comfort that came with the softened physical toil of the condition (WaW, ix)

${ }^{23}$ In a letter to his father in 1942 he writes, "I'll tell you about myself, I have been almost constantly on the move... I've become thin now. I weighed myself in the banya and it turns out I am only seventy-four kilos, and do you remember my terrible weight a year ago - ninety-one? My heart is much better... I've become an experienced frontovik" (WaW, xii). 
chemist, Grossman must have been accustomed to life as envisioned by the unison work of molecules cooperating to create sensations and actions during times of peace. War altered the fabric of the human body for Grossman. In Life and Fate, most depictions of the human body are hyper-realistic in their description of the carnage of battle, even though there is no gore. The exception being Sofya's death, where her body and her consciousness seem completely detached from physical death. Her body is communicated in its full humanity, but it is as if it had been transported to a different reality where death is not a function of life, but a condition of its own.

Woolf's recorded voice in the $\mathrm{BBC}$ broadcast comes to mind as a reiteration of art's promise to the human body. In a theme that will be taken up again in Chapter 2 in light of the technological aspects of memorialization, the impenetrable division between Woolf's voice and the recording of it is emblematic of the problematic relationship between text and body. We cannot have Woolf in hearing Woolf's voice because of the divide between the tapes in which the voice was recorded and the body through which the words were spoken. Woolf as a human being had a voice which cannot be accessed, in spite of its recording. Woolf's body can't be accessed for the obvious reason that Woolf is no longer alive, and so we cannot hear her speaking. Nevertheless, even though the strange power biding incarnadine to multitudinous seas cannot mend torn flesh, the past tense incarnation of memory will always invoke the humanity words cannot access. We have Woolf's voice and body, even if just as promises, in her art. That is the hope for art and the human mortality in times of war and in our means of remembering the dead. The human mind, revealed to its fragility in times of war, is always within the words we write. 


\section{Women as a New Perspective of War}

Before proceeding to the literary analyses of Between the Acts and Life and Fate, a last intersection between the works must be noted: both use female characters as the vessels for communication of memory. That is due to the insider-outsider social role experienced by women at the time of the books' productions. The gender of Miss La Trobe and Sofya Levinton mimics the insider-outsider perspectives articulated for Woolf and Grossman.

It is likely that if Sofya Levinton and Miss La Trobe had been male characters, their genders would have gone unnoticed. It is still a fact that female characters get noticed for their genders in literary criticism, and that reaction was exponentially stronger in $1940 \mathrm{~s}-$ especially in matters of war narrative. In the 1940s, women who were active members of society were insider-outsiders. Sofya Levinton and Miss La Trobe had jobs which placed them in the epicenter of war one as a military officer, and one as a civilian. The perspectives of women who were intellectually and physically in war, but were by default considered different from the typical soldier and civilian observer of war, offered the perfect mix of an involved but detached perspective for Grossman's and Woolf's fiction.

To this day, the image of women in WWII is deeply affected by the rhetoric created at that time and in the years that followed. The archetypes became pop culture icons: the scarlet-lipped nurse, the steel-eyed whip carrying SS officer, the villager on a summer dress offering flowers to liberating soldiers, and more gloomily, the black-and-white of a matron sitting among ruins of a bombed city, or perhaps staring hopelessly from behind the barbed wire of a camp. Even in modern days, it is still surprising to hear of a 
woman's perspective of WWII that does not fit these roles ${ }^{24}$. Sofya Levinton and Miss La Trobe embody none of those stereotypes, and because of that, their perspectives are automatically a fresh starting point for the memorialization of catastrophe in WWII.

Sofya Levinton's gender is crucial to the way in which Grossman tells the story of the character. Death camps were organized along gender lines. Grossman observed as much when he interviewed survivors from Treblinka and neighbors. ${ }^{25}$ Not only were people separated by gender and age to be executed, but the physical humiliation of men and women were also different. Grossman's notes from the front reveal some understandable difficulty in speaking of rape. There is an introductory note in which an older soldier jokes about sexual violence in war: "'Well, I remember the cavalry from 1914. They steal chickens and fuck women even as far as two hundred kilometers behind the front"' $(\mathrm{WaW}, 19)$, and then a note from a woman in liberated Paris implying rape by allies, "Monsieur, I love your army and that is why it is painful for me to see its attitude to girls and women. This is going to be very harmful for your propaganda" $(\mathrm{WaW}, 340)$, but he never names rape as a particular issue to be dealt with in open discourse.

\footnotetext{
${ }^{24}$ Not only was the life of civilian women as carried and intricate as the lives of soldiers, but there are also women who worked in or close to the front. WASPS, Night Witches, and female spies were an essential part of Ally and Axis forces. For examples of women's roles in WWII in literary and non-fiction accounts, see Mortal Storm by Phyllis Bottome, Not So Quiet, by Helen Zenna Smith, and Flying for Her Country: The American and Soviet Women Military Pilots of World War II, by Amy Goodpaster Strebe.

${ }^{25}$ His interviews and insight were published as "A Hell Called Treblinka" which was cited in the Nuremberg Trials.
} 
In "A Hell Called Treblinka, ${ }^{26}$ Grossman writes of a young woman who rebelled on her way to the gas chamber and took a gun from one of the guards. She was eventually subdued and tortured to death: "We are told about the tall girl who snatched a carbine from the hands of a Wachman on 'The Road of No Return' ${ }^{27}$ and fought back. The tortures and execution she was subjected to were terrible. Her name is unknown, and nobody can pay it the respect it deserves" (296). Grossman does not name her terrible torture as sexual violence, but rape was endemic in the camps, and Grossman would have known it.

Sofya also momentarily attacks a guard on her way to the chamber. However, Sofya is an older woman, an unlikely target of sexual violence even in a camp. It is possible to surmise that Grossman's choice to depict her as a virgin may function as assurance that she has not been raped. It is also likely that Grossman may have chosen to make her a virgin without giving any special meaning to the fact. In that case, the personal characteristic of being a virgin in her early 50 s is not a symbol for Sofya's representation, but a characteristic of her personality which reinforces her humanity. Grossman also may have been remarking that the only time Sofya exchanged looks with a man while undressed, that man was her executor. Sofya's gender serves not to define her, but to highlight experiences within a death camp that would be invisible to a male character's perspective.

${ }^{26}$ Grossman's published account of stories told by neighbors and 17 survivors from the camp, along with his personal reflection on what they said. The article was used in the Nuremberg trials as evidence against the Nazis.

27 The short path to the gas chamber in Treblinka. 
Miss La Trobe is a lesbian, and a woman who is clearly bothered by the fact that she must wear crinoline socks (203) and high-heeled shoes (210). The collective narrative voice of Between the Acts suggests that because of her bossy attitude and demeanor that “perhaps, then, she wasn't altogether a lady?" (58). It is not the fact that Woolf would be privy to a female and gay artist's point of view that makes Miss La Trobe's gender and sexual orientation relevant, but the fact that such a perspective was so unique at the time. In WWII, women were only beginning to take full participation in British society. The fact that Woolf elected to portray her war-time artist as a woman, and a gay woman, is a bold choice, since until that point in British history, the only role women had in war literature was to be killed, or to mourn the dead, regardless of sexual orientation. Woolf remarked in "Thoughts on Peace in an Air Raid" that women were entering a completely new realm of social identity in war:

Up there in the sky young Englishmen and young Germanmen are fighting each other. The defenders are men, the attackers are men. Arms are not given to Englishwomen either to fight the enemy or defend herself. She must be weaponless tonight. Yet if she believes that the fight going on up in the sky is a fight by the English to protect freedom, by the Germans to destroy freedom, she must fight, so far as she can, on the side of the English. How far can she fight without firearms? ... [there is a] way of fighting for freedom without arms; we can fight with the mind (173).

Miss La Trobe's pageant is the opposite of a direct intellectual fight against the Germans. There are many layers to Miss La Trobe's pageant that will be discussed in Chapter 2, but none of those layers is an attack against the enemy. 
In light of Woolf's quote, Miss La Trobe's artistic choice seems antithetical to Woolf's recommendation that women should fight with their minds. Miss La Trobe is a woman who is not behaving according to Woolf's own expectations of womanhood. Woolf's choice is explained by the fact that deemphasizing a prescription of gender (even one that is desirable according to Woolf's standards) frees Miss La Trobe's art. A male pageant director and author would not have allowed Woolf to perform the double-layered perversion of gender roles.

The ways in which womanhood is experienced in particularities and not generalities reinforces the fact that Miss La Trobe and Sofya Levinton are unmistakably people and not caricatures in representation. Since we know that Sofya was not raped, her existence is more complex. She has physical characteristics that are unique to her and determine her fate even as she is headed to death. The fact that Miss La Trobe is a woman who chooses not to write about social issues at a time when women were beginning to take on such subjects in their public lives, reminds us that she is an individual with her own understanding of private and public womanhood. Their complexity as individuals and the implications of their personal traits for the general artistic vision they provide speaks directly to the shifting dial between the private and the public in these works of fiction.

\section{Interpreting the Creation of Narrative as an Expression of Memory-Making}

The following two chapters will explore in detail how Woolf and Grossman used literary techniques to create memories of The Holocaust through Miss La Trobe and Sofya Levinton. Miss La Trobe will be presented as the journey from traditional historical archive that operates on public notions of truth to the new form of storytelling that must be created To speak of catastrophe, and specifically, of such as The Holocaust. 
Sofya Levinton will be presented as a journey from the collapse of the individual memory brought about by the certainty of death to a form of remembrance that comports that collapse, but transports it into a form of public memory that transcends the dissolution of a single individual. Together, both journeys articulate the most fundamental difficulties on memorializing The Holocaust. Chapters 2 and 3 will contrast Woolf's concept of storytelling and Grossman's concept of public memory so that jointly, they articulate the access contemporary generations have to Holocaust memories. The access will be expressed through the metaphor of sonic textures, or soundscapes, as modern readers must access the memory of The Holocaust as an invocation of the catastrophe: one that sends audible and viscerally palpable ripples through the historical record. 


\section{Chapter 2}

Remembering Fragments: The Collapse of Traditional Storytelling and the Dissemination of Memory in the Sonic Sphere

Virginia Woolf finished Between the Acts while the first news of The Holocaust started to reach public consciousness in England. As Woolf finished the manuscript, the first gassings in the camps had already begun. ${ }^{28}$ Though the specifics of what happened in the camps would not be known until after the war, that year, news of the Eastern front started to indicate the genocidal turn of The Third Reich's social policies. The text of the book is bursting with anxiety caused by nascent awareness of extent of the catastrophe. While Between the Acts wrestles with the immediacy of one afternoon's worth of anxiety for the war (most of the narrative is situated in the span of a few hours' entertainment during a garden party in the British countryside), it attempts to imagine what the lasting effect of the war will be on the future of civilization. In the book, The Holocaust is caught between the present tense and the expectation of future caused by the question of how Western society will remember it. This chapter will focus on the artistic necessity to make sense of the memory created by The Holocaust even while it happens.

The book expresses the will to articulate the tension between wanting to understand the current state of affairs in 1941 and the fear that the catastrophe will cause a fissure in traditional state memory. If traditional state memory cannot comport the catastrophe, its archival practices - organized by religion, Family, the State, etc.-collapse. In the book, the possibility of that collapse is expressed as a will to unpin the narrative from the

\footnotetext{
${ }^{28}$ As stated in Chapter 1, Woolf herself would listen to the news of the front that reached the British public through radio transmissions.
} 
present tense and thrust it forward toward the impending doom brought by war. The anxiety in the pages of Between the Acts reproduces both the immediate sense of devastation in 1941 and the memory that will come from these events.

To understand the will to unpin the present-tense narrative as an expression of messianic trauma, it is necessary to look at the role of the storyteller in recording history, the carnivalesque transformation of traditional memory expressed in the pageant that runs through the book, and the use of sound reproduction technology as an image of discontinuity and interrupted memory. ${ }^{29}$ Between the Acts expresses the diachronic effect of historical trauma on literary representation in its attempt to reproduce memory through literary images, especially those that are transmitted through sound.

Chapter 1 posed the relationship between readers' and author's awareness of catastrophe contained in the question "What about the Jews?" Here the question, which will be discussed in context later in the chapter, serves to conceptualize the first element of Holocaust memorialization in Between the Acts: how much palpable change had already occurred in traditional literature by the time the question was posed I Woolf's book.

The tension for the coming war Woolf captures in the book is heightened by personal concerns, but does not rely exclusively on them. Common sense may suggest that tragedy cannot enter the composition of a text unit after it happened, for instance, Natania Roosenfield poses in her "Turning Back: Retracing Twentieth-Century Trauma in Virginia Woolf, Martin Amis, and W. G. Sebald" that the true change to literature

29 The expression "messianic trauma" refers to the sense of catastrophe that has yet to happen, and therefore exists beyond the horizon of the future, but influences the experience of the present tense at every level. 
post-dates the loss of innocence of the war years: “... even after the world had lost [its] innocence, it still could not foresee the explosions or ovens of mid-century. Eventually literature would have to adapt itself to human acts that the worst horror fictions of Revelations or Dante never imagined" (109). However, as Claire Kahane states in her "Of Snakes, Toads, and Duckweed: Traumatic Acts and Historical Actions in Between the Acts": "Unlike her previous work, Between the Acts focuses on the anticipation of an actual catastrophe which it attempts to transmit to readers through novelistic form" (226). Kahane's understanding enforces the uniqueness of Woolf's text within the context of war-anxious literature because of the palpable tension from expecting actual catastrophe in the book through the posing of the question "What about the Jews?."

To assess the artistic need to articulate such tension in Between the Acts, it is necessary to look closely at the internal conflict experienced by the artist as the creator of national memory, a role embodied in the book by Miss La Trobe. Miss La Trobe, the playwright Between the Acts, is in a constant state of tension between her present circumstances and a broader sense of temporality she hopes to express in her art. La Trobe is as a representation of the narrative's tension between The Holocaust, happening in the present moment, and the representation of the event that is by definition cast forward into the future as a memory. She is in a constant state of anxiety while directing her pageant on the history of the British Empire.

\section{Miss La Trobe's Artistic Vision and the Collapse of Traditional Storytelling}

The bits and pieces of information provided about Miss La Trobe's background come from fragments of comments scattered in the general sonic texture of chatter from the audience throughout the narrative. The information gathered about the artist is 
relevant for this analysis, but the manner in which that information is conveyed is crucial to understand the role of soundscapes and sonic textures in the formulation of postcatastrophe memory. As it will be discussed in this chapter, Miss La Trobe and her pageant rely heavily on traditional means of communication: an artist speaks, an audience listens, and communication happens. The coming doom of The Holocaust means that form of communication is useless. While traditional artistic communication requires cooperation between artist and audience, communication that travels through a sonic texture is not limited to a willingness to receive logical inputs from agreed upon symbols and thought structures.

As we find out, Miss La Trobe is a woman of rumored Russian blood, a lesbian, a firm commander of her senses, and of the artistic vision of her pageant. Instead of knowing Miss La Trobe's first name, we have her nickname "Bossy" (57), and we have a pronoun "miss," also a noun signifying absence, and the last name that brings to mind immediate association with "trouble" or "trope." The omission of her first name places her textual intimacy in a texture of silence, a place where traditional communication cannot enter.

The absence of a first name limits any study of her traditional textual existence to her last name. Last names are formal and almost contractual. A last name inscribes an individual to a logical "order of things" where traditional history inscribes itself on the identities of individuals through the genealogy of a family name. Miss La Trobe's textual contract with that tradition is immediately put into question by the absence of a proper name. Instead of a last name that inscribes her into the history of traditional national 
memory, her last name is undercut by the absence of a personal identification displaced by a given name in the form of the pronoun/ noun/ verb "miss."

Her contract with traditional historical archiving places on the fault line between official State/ national history and the function of a storyteller for the modern times. "La Trobe" is linguistically cast in the etymological history of the image of the "troubadour" as a storyteller. The etymology of the word in The Oxford English Dictionary is traced to the Old French "turbare...to disturb, through the sense 'turn up'," and to the Medieval Latin "trope," and "tropus." In her family name, the etymology suggests the function of story telling and also the militaristic "troop."

Where Miss La Trobe is an embodiment of traditional historical record, she understands her own audience as troops she leads as an incursion into artistic communication. According to Miss La Trobe's understanding of art, she still has the job of communicating history to her troops: her audience. Melba Cuddy-Keane, in "The Politics of Comic Modes in Virginia Woolf's Between the Acts" points out the militaristic inclination of Miss La Trobe's personality: “As the creator of the pageant in Between the Acts, La Trobe is in a position to control the universe of the play, as a leader might exercise political control in society. "In one passage, La Trobe undoubtedly resembles a commander at war...." (278). The passage Cuddy-Keane refers to is:

Miss La Trobe was pacing to and fro between the leaning birch trees. One hand was deep stuck in her jacket pocket; the other held a foolscap sheet. She was reading what was written there. She had a look of a commander pacing her deck. The leaning graceful trees with black bracelets circling the silver bark were distant about a ship's length (62). 
The passage suggests traditional militaristic command of historical and artistic communication.

Miss La Trobe's carries none of the signals of the stereotypical tortured artist hunched over scribbling quietly in a dimly lit bedroom. She is Woolf's antithesis to her thesis in A Room of One's Own. ${ }^{30}$ Miss La Trobe is not in need of comfort to create art. She is "out and about," as are words, as Woolf refers to them in her BBC broadcast, in the thick of things, and needs no special circumstance to challenge the incommunicability of the human body. ${ }^{31}$ She is a character you could picture in the battle front, commanding troops and firing at the enemy, and yet she fails. Miss La Trobe's strategy is fundamentally flawed because of her trust on traditional storytelling. Woolf challenges that tradition by subverting it throughout the text of Between the Acts.

Miss La Trobe is a general drowning in strategy while the battle rages on. Unlike battles for territory, battles like the one Miss La Trobe is fighting transport the epicenter of the storyteller's angst into the future, where the memory of The Holocaust resides. Miss La Trobe's lack of capacity to bring her artistic vision into fruition is emblematic of the abject position of traditional storytellers in light of catastrophe. However, that abjection does not mean La Trobe should give up—all she can do is to see her pageant through. The disruptions in its presentation to the audience heighten Miss La Trobe's angst, but it is through those disruptions that Woolf manages to take the pageant beyond

\footnotetext{
${ }^{30}$ Woolf's 1929 A Room of One's Own called for the financial and emotional independence of women writers so that they could produce books under favorable conditions. Famously, one of those conditions was the privacy and tranquility of a room of one's own.

${ }^{31}$ The lecture, introduced in Chapter 1, will be brought back into the discussion later in this chapter.
} 
its artistic futility and transform it into an exercise in the processes through which modern storytellers build national memory.

The language of the passage in page 62 where the militaristic overtones of her personality are detected also suggests another important aspect of Miss La Trobe's role in the book: the frivolity of her attempts to implement her traditional understanding of history in performance. She has her "foolscap" in hand as she walks up and down the row of trees. "Foolscap" refers, of course, to the size of paper her manuscript is written in, but it also refers to the "foolscap" as "a cap of fantastic shape, usually garnished with bells, formerly worn by fools or jesters" $(O E D)$. La Trobe wants to harness her audience as a commander, but she is, at the same time, a fool.

Miss La Trobe is inscribed into the history of storytelling as the director of the farce not because she is a bad artist, but because of the undoing of traditional history by catastrophe. Benjamin's understanding of the novel as the erasure of storytelling comes into play insofar as it speaks to Miss La Trobe's failure to communicate her artistic vision. Though Benjamin attributes the collapse of the storytelling to the rise of the isolationist practices of storytelling, his premise is that the stories which fail to be told in modern times, fail because there is no longer a public common ground on which these stories can be shared:

The storyteller takes what he tells from experience- his own or what is reported by others. And he in turn makes it the experience of those who are listening to his tale. The novelist has isolated itself. The birthplace of the novel is the solitary individual, who is no longer able to express 
himself by giving examples of his most important concerns, is himself uncounseled, and cannot counsel others. (80)

Miss La Trobe cannot communicate her artistic vision because she is "uncounseled, and cannot counsel others." She is uncounseled because never before in human history had a storyteller had to communicate art in the shared public anxiety for the catastrophe that was to come in her years.

Though Miss La Trobe's failure is set from the moment she must use traditional storytelling to communicate the break with storytelling tradition, she is still in control of her own decisions as a producer of state memory. She was commissioned to write and direct the entertainment for an afternoon garden party of members of the defunct British aristocracy. She chose to write a pageant representing the history of the British Empire. Though the tone of the novel oscillates from a serious depiction of her state of mind and outright fun at her expense, the stakes in Miss La Trobe's mind are just as high about her pageant as they are for Wolf and Between the Acts in relation to The Holocaust. Woolf needs the traditional storyteller to feel herself in control even as that control slips from her because that tension is the material through which Woolf seeks to articulate the collapse of tradition. The actual developments of her pageant on the stage, the insight the reader has of Miss La Trobe's mind, and the crisscrossing of the narrative with plot developments represent the creation and presentation of national memory through art.

\section{The Pageant}

Miss LaTrobe's pageant functions both as a traditional record of the past in artistic form and as a subversion of that tradition. Miss LaTrobe and most of her audience members expect to see the pageant as a chronological expression of the history of the 
British Empire. However, the technological difficulties caused by a crackling gramophone, by the actors who forget their lines, and by Woolf's compositional choice of breaking up the pageant with thoughts from characters, and interjections from the narrative force throughout the book, interfere with the idea of traditional representation of history through art. To understand how the pageant expresses both the urge to preserve and understand traditional history, and the understanding that that tradition must be subverted To account for the catastrophe of 1941, it is necessary to look at the pageant in the light of contemporary theories on the public spectacle and processes of memorymaking that are present in festivals such as Miss La Trobe's play.

Though the seriousness with which Miss La Trobe takes the pageant is the principal tool through which Woolf verbalizes her own social angst as an artist, the tone of the pageant as it is presented through the narrative is predominantly one of self-mockery. Woolf scholars have discussed the comedic tone of the play for almost two decades. For instance, in two influential texts from the 1990s, Melba Cuddy-Keane considers it an actual play on the classic comedic genre. ${ }^{32}$ Meanwhile, Christopher Ames reads it as a

32 In her "The Politics of Comic Modes in Virginia Woolf's Between the Acts," Melba Cuddy-Keane describes this incomplete togetherness as an innovation by Woolf on the traditional Chorus of tragedy. She suggests that looking at the cacophony of character codependency as a tragic chorus (society from which tragic hero emerges) transplanted into a radically different comedic mode is a good way of understanding how these characters work in tandem so as to suggest an evolving, pulsating picture of individual characters in contrast to their environment:

In creating a distinctive choric voice, Between the Acts both returns to the ancient choral band and creates a comic mode. The new collective voice emerges through a subtle manipulation and transformation of [traditional comic modes]. Woolf inhibits her satiric impulse by modifying the satire with elements of amiable comedy and expands the amiable comedy with elements of liminality to create a subversive revolutionary mode, the art of the whole community. (276) 
Bakhtinian carnivalesque. ${ }^{33}$ This argument, however, does not place the comedy of the pageant on its internal satirical devices. The pageant is not an intelligent mockery of British history. It is a terrible pageant that reaches far beyond the scope of its actual purpose: to serve as an evening's entertainment for a garden party. The satire exists in the ridicule of traditional representations of history when it clearly no longer works.

The pageant is a failure first of all because of its technical characteristics. The actors are amateurs from the local village (and the audience members can recognize them throughout the play), the stage is out of Miss La Trobe's control because it is outdoors (people can't hear the actors at times), and the gramophone that is supposed to provide the soundtrack chirps and scratches, threatening to malfunction throughout the play. Though there are moments in which audience members seem legitimately entranced by the images and stories being told on stage, there is an overwhelming sense that the majority of the audience is merely going through the motions of watching a play.

There is a lack of willingness from her audience members (her troops) to surrender into the processes of nostalgia on which traditional historical archives base themselves. The scene in which "Queen Elizabeth" takes the stage is littered with a sense of mockery for the expectation of reverence for the image of the monarch. The audience is not

33 Ames' "Carnivalesque Comedy in Between the Acts speaks directly to the understanding of the book as a comedy because of literal parody in the pageant's plot: The festive subject matter and the concern with narrative multiplicity come together in the humor and comedy of Woolf's most explicitly carnivalesque novel. That comedy arises from parody, incongruity, and linguistic play-all forms characteristic of what Bakhtin calls the "public square"... My focus here is more explicitly on the parodic playlets of the pageantand the verbal play of the narrator and how these comic forms participatein the festive world of the carnivalesque novel (394-395). 
laughing and booing the actress of the stage. They are simply smiling and noticing her costume. However, the narrative voice, which is composed of collectivized reactions and background knowledge from audience members, remarks on the transparency of the act. The acknowledgement of accuracy in her costume and the overbearing awareness of her real identity as the tobacco dealer from the village, as well as the beauty of her garments, coupled with their recognition as household items creates a sense of quiet mockery for the spectacle on the stage:

Everyone was clapping and laughing. From behind the bushes issued Queen Elizabeth—Eliza Clark, licensed to sell tobacco.... Sixpenny brooches glared like cat's eyes and tigers' eyes; pearls looked down; he cape was made of cloth of silver-in fact swabs used to scour saucepans. She looked the age in person. And when she mounted the soap box in the centre, representing perhaps, a rock in the ocean, .... [s] he could reach a flitch of bacon or haul a tub of oil with one sweep of her arm in the shop. (83)

The audience acknowledges the tradition of representing monarchs as icons of imperial history, but because of the sense of collapsed history brought on by the certainty of catastrophe, Queen Elizabeth on the stage is only a carnivalesque parody of herself.

In How Societies Remember, Paul Connerton states: “A rite revoking an institution only makes sense by invertedly recalling the other rites that hitherto confirmed that institution. The ritual ending of kingship was a settling of accounts with and giving of an account of what it repudiated" (9). Though he is referencing actual public executions of monarchs in the passage, Connerton's analysis illuminates the interaction between the monarch and the audience in Between the Acts. Since of the looming certainty of 
catastrophe, there is a sense that the contract binding the British pubic to its history no longer stands absolute, while at the same time, the audience members cannot keep themselves from memorializing the present through a caricature of Queen Elizabeth. That is because instead of doing away with the tradition, the book seeks to articulate its crackling, flailing state of perpetuity in the modern times. A sixpence, saucepan-scouring fabric clad monarch personifies the tension.

Because the caricatured version of the traditional past is not created by Miss La Trobe's text, but by a living interaction between the audience, the material conditions of the play (in this case, the costume and the soap box), and the audience, the artistic experience is best characterized as a carnival. In Rabelais and His World, one of the foundational texts for the study of carnivalesque aesthetics in literature, Bakhtin states that the idea of the carnival (from the Middle Ages) infers a shared lived experience of art in which people experience the breakage of tradition (as revival and renewal) with in the form of a universal spirit:

Carnival is not a spectacle seen by the people; they live in it, and everyone participates because its very idea embraces all the people. While carnival lasts, there is no other life outside it. During carnival time life is subject only to its laws, that is, the laws of its own freedom. It has a universal spirit; it is a special condition of the entire world, of the world's revival and renewal, in which all take part. Such is the essence of carnival, vividly felt by all its participants.

The notion of state history being transformed into a carnivalesque representation of present moods is ideal for an understanding of Between the Acts as a rite of inauguration 
of post-catastrophe, or namely, the looming post-Holocaust experience of national identity.

\section{Sound Technology as a Game Changer for Memory}

In addition to the sense of farce caused by social sentiment in 1941, the idea of destabilizing traditional history for the sake of a form of remembering that includes the sense of doom triggered by the events of the year also is inherently tied to the development of technology at the time. In the 1940s, radios and gramophones started becoming integral part of people's everyday lives. Reproduction technology cemented the separation between experience and memory. In 1936, Walter Benjamin published "The Work of Art in the Age of Mechanical Reproduction." Benjamin, who would later die while fleeing the Nazis, was concerned that with the rise of technology, artistic expressions would become so devoid of physical presence that they would become exclusively the property of political exchanges. The root of the problem for Benjamin is the insulated nature of reproduced art:

Even the most perfect reproduction of a work of art is lacking in one element: its presence in time and space, its unique existence at the place where it happens to be. This unique existence of the work of art determined the history to which it was subject throughout the time of its existence. This includes the changes which it may have suffered in physical condition over the years as well as the various changes in its ownership. (218)

Though Woolf probably did not read the essay, a similar concern exists in Between the Acts. The soundtrack for the pageant is furnished not by a live orchestra, but by a gramophone. Since of the importance of its auditory presence in the book, the 
gramophone itself will be discussed later. However, before that analysis, it is necessary to articulate the importance of audio reproduction in Woolf's day.

Audio reproduction technology had been available since the first wax cylinder phonographs of the 1910s, creating a new element to the sense of physicality and embodiment of artistic communication. But in the 1940s, the technical capacity to disembody the human voice and transport it without imperiling the physical well-being of its speaker was first used as a weapon. Broadcast technology was pivotal in propagandizing purpose in WWII, and was crucial in spreading the horrible faith necessary to commit the most hellish and heinous instance of ethnic violence ever executed. The voices of dictators could now be disembodied and enter the houses of disembodied audiences, removing the human body from the equation of war propaganda. The implications of this disembodiment for artistic representation of the human body is palpable in Woolf's narrative.

As discussed in Chapter 1, Woolf delivered a lecture on the act of writing and the limitations of the English language. Woolf delivered the text of the essay as a recorded $\mathrm{BBC}$ radio broadcast, and this passage still exists as a fragment of the only surviving recording of Virginia Woolf's voice. The passage is remarkable in terms of content, but that is not the only reason why it is remarkable. In the recording, the portion which follows the first dash begins "but we cannot use them because the English language...." Here, the recording crackles and stops. Her voice returns after the pause to begin the next sentence. But the silence cannot be ignored. The recording is not defective because it became damaged over the years, or because of a recording error, but because it was damaged in the bombing of London by the Nazis. 
Woolf's recorded voice is a reiteration of art's simultaneous recalling and dissociation of human experience. The impenetrable division between Woolf's voice and the recording of it is emblematic of the problematic relationship between memory and reproduction. We cannot have Woolf in hearing Woolf's voice for one basic reason: the physical detachment between the tapes in which the voice was recorded and the body through which the words were spoken. Woolf as a human being had voice which cannot be recalled, in spite of its recording.

\section{The Gramophone}

As Miss La Trobe agonizes over her artistic vision and tries to entertain upper middle class English men and women in the garden of an old country house with her pageant, bombers are flying overhead. The airplanes belong to the sonic texture of the book. However, instead of having the sound of the airplane engines punctuate the narrative, she uses the chirping of a gramophone. Equally disturbing to the pacing of the pageant, the sound of the chirping of the gramophone gives a textual avenue to the sounds of war that accompany the notion of state history in Western Europe after 1941.

The gramophone plays in the background through most of the book, providing a soundtrack and a sonic disturbance for Miss La Trobe's pageant. The contact between needle and vinyl causes a chirping sound that plays throughout the text of the book. The refrain "the gramophone crackled" is repeated at exhaustion throughout the novel. The word "crackling" infers a malfunction. Crackling seems in many ways antonymous to "solid" or "insoluble." The intersection between the plasticity and resilience of reproduced art and the fragility of the crackling sound embody the simultaneous presence of catastrophe in state memory and the impossibility of ever hearing its presence because 
of the very fact that the archive is reproducible, while the human flesh that perished in the Holocaust is not.

Though it may be tempting to read the crackling gramophone as technophobia, or as an omen to contemporary posthuman preoccupations, the malfunctioning technology is more than that. ${ }^{34}$ The crackling and failing gramophone of Woolf's narrative is also more than a political warning against the rise of fascism in Europe. The faltering machine creates an embodiment of fragility for artistic communication. The reproduction of a gramophone recording is supposed to be the true likeness of the human form, but true likenesses are hopeless against the shifting experience of human embodiment. The crackling gramophone can be read as a refusal by the human body to be e removed from artistic signification at times of war.

The gramophone is also responsible for one of the most evocative refrains in Between the Acts: "Dispersed we are" is a sentence that repeats throughout the narrative. In utilitarian and literal terms, the call signifies the end of each act for the pageant. However, the significance of the refrain goes far beyond its original role. The statements is evocative of the fragmentation of memory caused by the ripples of catastrophe reverberating in the public consciousness of Western Europe at the time, but even more

34 One of the leading scholars in posthuman literary theory, Cary Wolfe, states: "[posthumanism] comes both before and after humanism: before in the sense that it names the embodiment and embeddedness of the human being in not just its biological but also its technological world, the prosthetic coevolution of the human animal with the technicity of tools and external archival mechanisms..." (What is Posthumanism?, xv). Since Woolf's use of the crackling gramophone is undeniably suggestive of a sense of apprehension toward technology replacing human storytelling, it is important to disambiguate that for the purposes of this argument, the archival mechanisms of the crackling gramophone are not a commentary on the effect of technology on the question of human consciousness. 
importantly, it invokes the dead. In a theme that will be taken up again in Chapter 3, the transformation of memory from the ending of a single life toward the public reconnaissance as that death being part of a public catastrophe is best articulated as the notion of dispersing, or being dispersed. In that case, it is not the undoing of bodies that represents individuals in the sonic texture of the gramophone, but their palpable physical presence in the memory that is created of their death by the processes of remembrance in Holocaust novels.

\section{Sonic Disturbances as Reflection of Fragmented Memory}

Because the crackling of the gramophone is repeated as a chorus throughout the book, there is a sense of fragmented continuity that mirrors the collapse of chronology of memory because of catastrophe. Fragments are made to be part of an audible disturbance of the pageant because of the crackling gramophone. For that reason, when the most direct reference to The Holocaust happens in the book, the physical fragmentation of the passage can be heard as clearly as it can be visually comprehended through the use of ellipses:

And what about the Jews? The refugees . . . the Jews . . . People like ourselves, beginning life again ... But it's always been the same.... My old mother, who's over eighty, can remember ... Yes, she still reads without glasses. ... How amazing! Well, don't they say, after eighty . . . Now they're coming ... No, that's nothing. ... I'd make it penal, leaving litter. But then, who's, my husband says, to collect the fines? ... Ah there she is, Miss La Trobe, over there, behind that tree ... (104) (All Woolf's ellipses). 
Even the semblance of an answer for the question "What about the Jews?" comes in the form of a fragmented inability to complete the thought.

\section{Miss La Trobe's Physical Reaction to the Fragmentation of Memory}

During that passage, Miss La Trobe is hiding behind the bushes, almost as if in a trench, looking at the gathering audience as they settle on their seats to resume the play's action after a break. Her reaction can be analyzed as a physical manifestation of the problem Benjamin outlined in his essay. Metaphorically, Miss La Trobe's physical presence in the scene acts like the tape that cannot convey Woolf's voice in the BBC recordings, or like the mechanically reproduced work of art that cannot have any authenticity other than its political value.

As the figure of the storyteller, Miss La Trobe is at the epicenter of communicated national identity and catastrophe as they collapse into each other's limits: "Over there behind the tree Miss La Trobe gnashed her teeth. She crushed her manuscript. The actors delayed. Every minute the audience slipped the noose; split up into scraps and fragments. “Music!” she signaled. "Music!'... [a]nd the gramophone began" (122). Miss La Trobe clamors for music as if in an attempt to solidify the fragments of communication that dictate the connection between her and her audience. What she fails to realize is the music is equally fragmented. Not only will the music be played through the crackling gramophone, but the music is already of the dead.

Miss La Trobe tenses, gnashes her teeth, and crushes her manuscript. It is as if her artistic vision and her foolscap want desperately to exist in the same plane, but they can't. The word "manuscript" can be unpacked as a linguistic expression of the fragmentation of art in Miss La Trobe's gesture. "Manu," or "hand" can stand for flesh and for presence 
before it unfolds before the creation of a memory, and "script" can stand for representation, or the communication of a memory. When Miss La Trobe crushes her manuscript, the gesture exemplifies her urge to maintain the connection between presence and memory, or flesh and representation, or catastrophe and traditional national history.

However, just as the music is already fragmented by the physical presence of the crackling gramophone and by the carnivaleque experience of the pageant, hand and script cannot be made to exist in unity anymore. Her hand cannot enter her text, as flesh, paper, and printed words cannot exist as anything other than separate physical entities. The moment is the epicenter of the nervousness for the coming catastrophe in the book. As she stands behind the tree and gnashes her teeth, La Trobe is at the edge of textual expressivity.

The language of the text joins the ripples of The Holocaust in yet another form: the use of biblical imagery of hellish furnaces in a place of "gnashing of teeth." The expression "to gnash her teeth" invokes he biblical passage from the Judgment Day:

The Son of Man will send forth His angels, and they will gather out of His kingdom all stumbling blocks, and those who commit lawlessness, and will throw them into the furnace of fire; in that place there will be weeping and gnashing of teeth. English Standard Version, Mathew 13:42

Woolf's use of the biblical vocabulary strikes the contemporary reader through the diachronic effect of catastrophe on linguistic memory. As contemporary readers, furnaces, fire, and weeping, in a text that asks about the fate of the Jews in 1941, triggers the association with the etymology of the word "holocaust": " [a] biblical word meaning both 'a sacrifice wholly consumed by fire; a whole burnt offering,' and '[c]omplete 
consumption by fire, or that which is so consumed; complete destruction, esp. of a large number of persons; a great slaughter or massacre" $(O E D)$. To the modern reader, especially those familiar with the Nuremberg Trials, where Grossman's “A Hell Called Treblinka" was used as evidence to incriminate Nazi war criminals, the furnaces have a very specific denotation: the image of the pits dug on the ground in Treblinka as Grossman described them. ${ }^{35}$ The furnaces of Treblinka are perhaps the inspiration in a powerful passage of Life and Fate, to be discussed in detail in Chapter 3:

To the north-east there was a dark red glow in the sky; it was as though the damp autumn sky had somehow become red-hot. Sometimes a low, creeping flame escaped from this damp glow.... [Prisoner musicians start playing, and] air that had been torn apart by barbed wire and the howl of the sirens, that stank of oily fumes and garbage—was filled with music. It was like a warm summer cloud-burst ignited by the sun, flashing as it crashed down to earth" (539).

35 Grossman writes that after the number of dead far surpassed the capacity of the mass graves dug around the perimeter of the camp, Himler himself was sent to Treblinka to oversee the development of ground-dug furnaces that would destroy the bodies before the imminent arrival of the Red Army:

Onto each furnace-grill, 3500-4000 corpses were loaded simultaneously. People who took part in burning the corpses say the furnaces were reminiscent of gigantic volcanoes. A terrible heat burned the faces of the workers, flames grew eight to ten meters into the air, pillars of thick and greasy smoke reached the sky and hung in the air in a heavy immobile cloud....This monstruous workshop operated day and night for eight months and couldn't cope with the millions of buried human corpses... (300-301). 
The biblical ramification of Miss La Trobe's confrontation with the fragmentation of memory post-catastrophe brings the analysis to its final point before the exploration jumps to the historical hindsight of Grossman's novel: the naming of The Holocaust.

For a modern reader, the word "holocaust" has only one meaning: the genocide of the Jews in WWII. However, before the analysis shifts to the post-Holocaust era with Grossman, it is necessary to remember that for Grossman, the catastrophe remained unnamed throughout the composition of the novel. For Grossman, writing of The Holocaust in hindsight still meant speaking of it without the linguistic signifiers that help modern readers conceptualize the extent of the catastrophe. Both for Grossman and for Woolf, the genocide of the Jews existed in a linguistic limbo where no words had yet been chosen to represent it. Holocaust literature in the decade separating Between the Acts and Life and Fate was the work of fighting the rigidity, tradition, and limitation of language, so that at least some words could be thrust into the ripples of memory and become responsible for what modern readers can understand as the vocabulary of The Holocaust: a vocabulary with its own sonic texture, communicated within its own soundscape. 


\section{Chapter 3}

In Excess of Materiality: The Soundscape of Death Camps as a Vehicle for Diasporic Memory

Vasily Grossman's Life and Fate navigates one of the foundational issues in Holocaust literature: the economy between historical fact and literary representation. Grossman's narrative navigates the borders of fact and representation, private and public spheres, and death and resistance. In one of the central chapters of the novel, Life and Fate deals with the Holocaust as both a material fact that needs to be archived in official State history, and as an event that exceeds the regular implication of material history. ${ }^{36}$ To appreciate the different forces at work in the book, this chapter will engage the novel's treatment of catastrophe through the time warp of trauma: the collapse of private and public memories caused by the transformation of an event into the diasporic past, and the diasporic thrust of that memory into the future. The time warp is evident in the tapestry of invisible sounds, rhythms, echoes, and music that interweave the narrative. To reveal the will to sublimate and recuperate the traumatic past in Grossman's narrative, this argument will analyze the treatment of clothing, flesh, and other material objects in light of the soundscape of the narrative. ${ }^{37}$ The literary music-ethnological analysis of Grossman's

\footnotetext{
${ }^{36}$ A definition of the concept of cultural archive can be found in Chapter 1.
} 
treatment of The Holocaust allows for an exploration of diasporic fiction of catastrophe in the way it comes to be understood in the latter $20^{\text {th }}$ century and beyond.

The previous chapter has demonstrated the affliction of the pre-Holocaust Holocaust novel as the starting point of the fragmentation and dispersion of sonic memories of the dead. This chapter will demonstrate how the post-Holocaust Holocaust novel struggles to make audible the ripples sent forth through the cultural soundscape at the moment of the catastrophe. The act of listening to the dispersed sonic texture of The Holocaust in Life and Fate and beyond can be understood as the inauguration of a diasporic movement of sonic memory triggered by the Holocaust. ${ }^{38}$

The chapter situated at the physical mid-point of Life and Fate narrates the arrival of a load of prisoners to an unnamed death camp. ${ }^{39}$ One of the prisoners is Major Sofya Osipovna Levinton, a Jewish Red Army medical officer. During her transportation to the camp, we find out that Sofya is a secular Jew who practiced medicine in Berlin for nearly 30 years before the war. In the train journey, her internal dialogue oscillates between

${ }^{37}$ As defined in Chapter 1, soundscapes are the unseen and immaterial layer of sound that runs through a text of trauma that manifests itself

${ }^{38} \mathrm{~A}$ diasporic movement is a movement of dispersal from a point of origin (usually traumatic).

${ }^{39}$ Adriana Cavarrero's commentary on the lack of vocabulary for evil sheds light on the significance of the anonymity of the camp:

Names obviously do not change the substance of the epoch that has managed to write the most extensive and an anomalous, if not the most repugnant, chapter in the human history of destruction. Nor can the crude realities of bodies rent, dismembered, and burnt entrusts its meaning to language in general or to any particular substantive. Yet on closer inspection, violence against the helpless does turn out to have a vocabulary of its own (3). 
hopelessness caused by hunger and thirst, resistance brought about by her own

subversion of the social structure and material confinement of the train compartment, and wondering how the memory of her death will reach public consciousness.

The memory of genocide, like the memory of slavery, surpasses the numerical accounting of the dead or the enslaved. ${ }^{40}$ What Grossman's narrative emblemizes through

Sofya's concern for the memory of her own death is the archiving of catastrophe that

exceeds the material circumstances of the historical event. That memory must be unpinned from the fixity of linear communication and understood as a score that operates as an extension of human memory. That extension is capable of telling a cogent narrative by invoking secrets that exist beyond traditional recollection. In this case, the buried secrets are the lives of the actual dead in The Holocaust, as are the memories of the actual enslaved persons in the Transatlantic Slave Trade. The memory Grossman's narrative can summon is a musical memory that transposes the limitations of historical secrecy. ${ }^{41}$

Before embarking on the soundscape analysis of the camps in the narrative, it is necessary to disambiguate the utilitarian tasks of music in the process of memorialization

\footnotetext{
40 Toni Morison's famous dedication in Beloved "Sixty Million and more" expresses the impossibility of relying on a quantitative notion of the number of the dead or the enslaved in archival fiction. Her words "and more" signify the immaterial aspects of memory that are recorded in literary soundscapes.

41 Jean- Luc Nancy's 2007 Listening works with the power music has of keeping and revealing secrets through sonic utterance. The characteristics of witnessing afforded by the act of listening surpass the limitations of traditional historical records discussed by Michel Trouillot's Silencing the Past: Power and the Production of History. Trouillot's commentary on selective archiving is especially relevant for Life and Fate because of the novel's difficult relationship with censorship.
} 
of the dead both inside and outside the environment of historical death camps. ${ }^{42}$ Music can be employed as eulogy, invoking the acceptance of death and its irrecoverability, and the ritualistic recalling of the dead in the song of the living. Both works of music imply the necessity to reach the memory of the dead. In the death camp, the dead are neither eulogized nor ritualistically recalled because music is meant to erase them from the invocations of the music being performed. ${ }^{43}$ The soundscape of historical death camps is the music of death because of its means of production. Performed by prisoners, themselves condemned to die, mixed in with the other elements of the soundscape: screams, barked commands, nose sniffs, digging, burning, picking through clothes, shuffling of feet, the materiality of music is radically altered into being something other than itself. The music of historical death camps cannot even be said to be materially identical with the same score performed in the memory of the prisoners that heard and recognized the melodies.

\footnotetext{
${ }^{42}$ Chapter 2 defined the role of Walter Benjamin's essay on the mechanical reproduction of art and its effects on political and social value of art. Here, a different aspect of the essay must be taken into consideration: his take on authenticity. The essay addresses the reproducibility of art in the scheme of material technology in his "The Work of Art In the Age of Mechanical Reproduction." He claims that there is a fundamental difficulty in registering the original manifestation of art in the mechanical reproduction of the artistic object. Benjamin's piece brings to light the chance for communication of the "aura" in phenomenological terms in the case of literary soundscapes. The presence of "the aura" insinuates itself to the reader beyond the materiality of the book as a historical object and beyond the codification of words within the narrative. The event expressed through the aura (The Holocaust, Sofya Levinton, diasporic longing, etc) reaches the reader in excess of materiality and utilitarian reproduction.

${ }^{43}$ They are works precisely because of their utilitarian nature. The work of music is emblemized by the vocabulary of musical archiving such as the words "opus" and "oeuvre," both highlighting the "work" of music as a task.
} 
The soundscape of the camps in diasporic memory, however, imbues the descriptive language of the narrative with additional archival power. ${ }^{44}$ In the scene when the prisoners arrive at the camps and disembark the train, they are led to a "spacious square" where musicians are gathered "on a wooden bandstand like in a public park" (539). If the landscape of the scene is stripped from its sonic element, the narrative would be stuck with the impenetrability of the physical space of the camp-it would be stuck in the material world of historical camps. Understanding the scene through its soundscape reveals an additional layer of Grossman's narrative and its power of representation. The language of the scene is ripe for a sonic reading:

...they reached out for their instruments. There was the burst of something like cheeky, timid bird-song and the air—air that had been torn apart by the barbed wire and the howl of sirens, that stank of oil fumes and garbage — was filled with music. It was like a warm summer cloud-burst ignited by the sun, flashing as it crashed down to Earth (539). Here Grossman's language weaves between physical realism, physical metaphors, and immaterial physicality. He dismantles the impenetrability of the physical materials by bringing to the forefront the piercing properties of sound. For instance, "barbed wire" is transformed by "sirens" as the sharp metal of the first is transposed into musical memory

\footnotetext{
${ }^{44}$ Archiving diasporic longing through soundscapes must also be connected to silenced histories. Michel Trouillot traces that political silencing in his "Silencing the Past: Power and the Production of History." Reading the soundscapes of narratives does not fix the problem identified by Trouillot, but it adds an interpretative layer to the texts in academic canon, pop culture canon, and in unknown texts.
} 
by the sonic properties of the latter. Barbed wire can be stretched beyond its immediate place and space in time. It becomes part of a soundscape memorialization.

The same effect is felt in the flesh of the prisoners and perpetrators. When Grossman's narrative describes the effects of music on the prisoners themselves, he assumes a particular narrative stance that resembles a collective first person more than a regular third person account. The shift occurs after he states, still as a detached narrator, "People in camps, people in prisons, people who have escaped from prison, people going to their death, know the extraordinary power of music"(539). After that, the narrative assumes a collective first person that gives the reader access to the role of music/soundscape as an archiving mechanism of individual persons within the public sphere of the camp:

Everything seemed transformed, everything had come together; everything scattered and fragmented-home, peace, the journey, the rumble of wheels, thirst, terror, the city rising out of the mist, the red dawn — fused together, not into a memory or a picture but into the blind, fierce ache of life itself.... In the same way, a child's song can appear to make an old man cry. But it isn't the song itself he cries over; the song is simply a key to something in his soul" (539-540).

The transformation or fusion expressed in the passage encompasses the effect of music on archiving the human body. Atemporal expressions of flesh, history, crimes, and their transcendence are fused together as a single phenomenon through sound.

The transformation, however, would be invisible without a single, particular human mind that takes the fusion of material and immaterial memory to the singular 
history contained in an individual human experience. Sofya Livinton' thoughts at this point in the narrative encompass the complex dialogue of music inside a death camp: "She had first heard this piece when she was a child...It always filled her with a keen sense of the future. But this time the music was deceptive. Sofya Levinton had no future, only a past" (543). Immediately after taking the soundscape of memory into Sofya's private mind, Grossman transposes the narrative into free indirect discourse. He is not narrating Sofya's thoughts as much as he is allowing her dialogue with the music to become the narrative voice. The passage is a hybrid moment of textual agency shared by character and author:

It was the very strangest of feelings, something you could never share with another person - not even your wife, your mother, your brother, your son, your friend or your father. It was the secret of your soul. However passionately it might long to, your soul could never betray this secret. You carry this sense of your life without having ever shared it with anyone: the miracle of a particular individual whose conscious and unconscious contain everything good and bad, everything funny, sweet, shameful, pitiful, timid, tender, uncertain, that has happened from childhood to old age - fused into the mysterious sense of an individual life. (543)

The passage incorporates the secret of Sofya's individual life into the revelatory powers

of music. Without spelling out the secret of Sofya's mind—something that is impossible to linear textual representation-the narrative invokes her secret into the tapestry of 
invisible immaterial sounds that compose its soundscape. The actual song also remains a mystery. Grossman does not name the composition. The sound of an unnamed song, together with the terrible sounds of the camps, becomes an archive in which Sofya exists both in transcendence of her material conditions, and as a historical victim in a factual event. The blending of physical and memory archival of which soundscapes are capable is defined by John Scanlan: "Bridging the realms of the material and the immaterial, the auditory world exists at the intersections of time, space and body" $(20) .{ }^{45}$ Sofya's body is memorialized in a soundscape that escapes the employment of utilitarian forms of music and becomes part of a phono-literary memory.

\section{Silence}

The soundscape of death camps is composed of equal parts sound and silence. To understand the complete effect of sound in Grossman's narrative when Sofya reaches the camp, it is important to discuss the absence of sound in her world. When she first steps out of the train compartment, there is silence and interruption of silence: "There was a grinding of brakes and the wagons squealed to a halt. A moment of quiet was followed by the rattle of the order 'Alle heraus!'”(537). Here, silence expresses both the gap now separating Sofya from the public sphere, and it also symbolizes resistance. When the guard orders her to walk, she must walk - there is no possibility of disobeying. However, Sofya's own silence is not interrupted by the guard's order. She walks in her own metaphoric pause in the score. We only hear Sofya's thoughts again when she is reacting

\footnotetext{
45 "Fragments Of Time And Memory: Matter, Media And The Modern Auditory World." European Journal Of English Studies 15.1 (2011): 19-29.
} 
to the music. The choice amplifies her reaction as a fortissimo in the narrative after the silence. $^{46}$

Silence is also important at this point of the narrative because it embodies one of Sofya's greatest acts of resistance. Immediately after the introduction of the orchestra, a guard approaches the incoming prisoners and demands: “'Doctors! Surgeons!' No one responded. 'Doctors, surgeons, come forward!' Again—silence. The officer walked back to his car. He had lost interest in the thousands of people in the square" (540). Sofya is a doctor, and she says nothing. Grossman could have chosen to state Sofya's thoughts as a choice to remain silent during the narrative of the scene. However, allowing the question to ring out unanswered moves Sofya into a position of agency and authorship for her own score. Sofya is not replying to the order with silence, she is piercing the guard's material power over her with a sonic indifference. Later in the narrative, on Sofya's own internal time, we hear a more detailed account of her reasons for not coming forward as a doctor. Though saving her life because of her profession was tempting, definitions of profession and rank no longer informed her notion of self. Sofya had silently won a battle against material survival in favor of her own agency:

When they had called for the doctors and surgeons, she had remained silent, fighting against some powerful force that she had found repugnant. ... She didn't want to admit why she hadn't answered when they had called

\footnotetext{
${ }^{46}$ Fortissimo is the loudest inscription of musical dynamic in written score.
} 
for doctors and surgeons, why she had been seized at that moment by a feeling of exaltation. (544-45)

Finally, the music stops. When it does, all of the secret undecipherable past contained in the narrative memory of Sofya is expressed by the following: "When the music stopped, Sofya Wiped away tears and said angrily: 'Yes, it's just like what that poor man said!'” (544). Sofya had been crying while the music played unbeknownst to the reader, the narrative, and perhaps even to herself. The secret of her internal life brought forth by the music — physically expressed by the tears — belongs to an inexpressible experience of humanity. It belongs to the diasporic eulogy of the dead. The reader does not get to find out who "that poor man" is either. He may have been anyone: a rabbi with words of wisdom on death, a dying patient on a surgery table, a dying wounded soldier, a stranger who understood the extent of the Holocaust while it unfolded, the author of the music, or it might have been a madman. Those are Sofya's last audible words in the open space of the camp before she enters the undressing room of the chamber. They are said to no one and to the whole world at the same time. They have no meaning and they have infinite meaning. All her subsequent spoken words are inserted in a narrative expression in which language operates beyond the reach of public discourse in the narrative.

In 2011, the BBC produced a radio version of Life and Fate as a 7-hour adaptation that features some of the key moments in Sofya's narrative. The entire recording is heavily stylized: it features completely rewritten passages and a very dramatic musical soundtrack. Without entering a reading of the recording itself, one of its most striking characteristics when Sofya walks toward the chamber can be brought to 
bear on this reading. Once Sofya approaches her death (with completely rewritten internal dialogue), the background sound and music stop. Only the actress' voice is audible. In the recording, silence expresses a moment of private thought that even the soundscape of the camps cannot penetrate. In this reading, the soundscape does not stop when the music ends.

\section{Clothing as an Exchange with Identity in Representation}

From this moment forward in the narrative, Sofya is naked. Clothing is the most visible aspect of cultural embodiment. Attire creates a physical expression that overlaps nuances of character with the stratification of a certain society and a person's place in it. ${ }^{47}$ As she is gradually undressed in her journey to the camp, the soundscape of the narrative transposes her nakedness and her clothing into notes on the score of diasporic memory. To express the place of Sofya's nakedness in the narrative, the reading must circle back to her initial appearance in the novel and read the dialogue between clothing and flesh, and clothing and society as a form of material and immaterial archive. Once the narrative reaches Sofya's nakedness in the camps, its place in the soundscape of the narrative will be made apparent.

When Sofya first enters the narrative, Grossman emphasizes the shift in dialogue between Sofya's profession and Jewish identity and the newly established public notion of Nazism by highlighting the fact that her insignia was torn from her clothing upon her capture: "[T]he insignia of rank had been ripped from her uniform. The look of sullen

\footnotetext{
${ }^{47}$ Paul Connerton's How Societies Remember speaks to the different ritualistic roles of embodiment in social memory.
} 
hatred on her face had filled Mostovskoy with admiration" (24). The torn uniform signifies that the absence of the item is still present in her clothing. The hole in the uniform does not mean her rank is gone, the hole states publicly that the insignia is there, more visible than ever, but that it now is a symbol of the economy of demonization.

The economy of clothing intersects with the way in which Sofya's flesh is restated within a dialogue with the public sphere. However, it is not possible to speak of clothing in isolation of flesh. Her body is marked for destruction from the moment of her capture while her clothing is destroyed as a representation of that corporeal marking. Clothing simply offers a specific aspect of textual access that is not available to a person's body. In Grossman's controlled narrative environment, clothing goes through the same violence as Sofya's body, and it behaves as a Husserlian approximation of the epoche. $^{48}$

Grossman does not shy away from the fact that human flesh offers an insurmountable barrier to polemic narrative. Instead, he incorporates Sofya's body into her economy with the public sphere. Sofya has "pathetic dreams" (196) of a warm drop of liquid in the bottom of a rusty can within the first pages of her narration in the cattle car shortly before stumbling over David's small body. In the following passage, Grossman offers a mechanism for subversion of physical constraints that does not erase the insurmountable reality of Sofya's surroundings.

\footnotetext{
${ }^{48}$ In "The Second Cartesian Meditation" the idea of "intentionality" is a function of knowing which commits to the necessity of knowing, but never reduces knowing to qualified or quantified cogitations. That function allows for the epoche to be intended aesthetically without the brokering agency of a Cartesian ego cogito. At this intersection of phenomenology and aesthetics, the epoche can still be intended toward and discerned through phenomenological reduction, but they cannot be known.
} 
However, Grossman offers the beginning of a physical counter-narrative to Sofya's bodily powerlessness when she rips a piece of the hem of her skirt and pushes it through a chink in the wagon To catch rainwater: "Sofya tore a slip from the hem of her shirt, made her way towards the wall and pushed the material through a small chink (199)." The action at first glance seems to be continuing the undressing process initiated by the ripping of Sofya's uniform insignia, or evidence that Sofya is losing possession of her own physicality by losing more of her garment. In fact, Sofya's tearing of her own clothes reflects a complete reformulation of physical self-possession in the novel.

Sofya's act of ripping off a piece of her own shirt is also a gesture of radically transforming the utilitarian design of her clothing. The fabric covering her body at first inscribed rank and national allegiance to her body. Then it became the tattered clothing of a prisoner. Sofya disowns the power ascribed to her garments by turning the fabric into a water-catcher, the tool of physical necessity as opposed to a symbol of social order. The act also brings to question the materiality of the train compartment as a border encompassing Sofya's possibilities of physical agency. Sofya's act of transgression has the obvious connotation of breaking the internal confinement of the train as a personal act of resistance against forces exterior to her. However, the moment gains a new dimension if Sofya's intrusion of the public sphere is read as dissemination of trauma into the exterior world. Just as clothing offers a phenomenological pathway to a body that cannot be reached, the physical material of the train compartment, as Sofya pushes a piece of her ripped shirt through it, becomes a tangible expression of memory. It is as if Sofya, as an embodiment of diasporic trauma (always messianic in that is "to come" and ever-present), 
is pushing Grossman's narrative to a place beyond the constraints of an immediate political reaction against a factual tragedy. Once Sofya pushes her ripped shirt through the chink in the train, her narrative becomes unpinned from time and place.

\section{Rejoining the Score of Memory through Nakedness}

Once that trauma is out in the open, Grossman's narrative is metaphorically transported beyond Sofya's own flesh and blood without disregarding the fact that her narrative is affected by her own personal thirst, pain, and hunger. The effect resembles the gradual dissemination of awareness of the Holocaust in Grossman's own environment. The Soviet leadership had no interest in acknowledging genocide against the Jews, since WWII was portrayed exclusively as a patriotic war against fascism, and a different narrative, even if not opposed to it, was immediately stiffened. The dissemination, however, is more than an the necessary maneuvering of specific historical settings. All trauma is a secret. As the last lines of Paul Celan's poem Aschenglorie, "no one bears witness of the witness." 49 The only way trauma enters the public sphere, since it cannot be told in specific factual terms, is by a gradual dissemination- to borrow from another of Derrida's terms. Trauma as a memory in the public sphere must come to inhabit, by dissemination, a material immateriality, or a physical existence that is not bound to the present moment. Hence, Sofya's flesh, clothes, and nakedness reenter the real that is only accessible to music in the narrative.

${ }^{49}$ Jacques Derrida offers a detailed reading of the poem in its theme of inaccessibility and revelation of trauma in "Poetics and Politics of Witnessing" in Sovereignties in Question: The Poetics of Paul Celan. 
The same way material existence and reading become entangled in a reading that acknowledges the dissemination of trauma in the public sphere, Sofya's own physical existence becomes not only of herself but also of bodies adjacent to her. In the journey, Sofya had met David, a 6-year-old orphaned Jewish prisoner. Without giving away their own existences as persons within representation, they become their bodies as we remember them in a diasporic soundscape. While they are inside the train compartment, and later, when they are inside the gas chamber, Grossman's narrative strives to reinforce their physical existence as aesthetically realistic human beings. However, as soon as they step out of the train compartment, their physicality begins to be replaced by a necessity to transfer their existence into the realm of musical memory.

When the prisoners arrive at the camp and physically leave the train compartment—where music enters the narrative- - their bodies are not dissolved, but disseminated into the representation public memory of trauma in literature. On page 537, as they are disembarking, he says: "Their clothes had changed less than the people themselves. Coats, jackets and shawls called to mind the houses where they had been put on, the mirrors in front of which they had been measured." In the context of clothing as a dialogue with the public environment, the conversation of clothing and memory ends at this point in the narrative. Their bodies occupy a place of material immateriality that goes beyond the invocation of the social place inherited by their clothes. The clothing remains a physical manifestation of the space they occupied within the public sphere before the trauma. Now their bodies are stripped of that kind of social belonging, though they are still clothed at this time. It is as if clothing is already implicated in the time warp of diasporic memory. 
In Chapter 2, Miss La Trobe's gramophone sounds out a refrain throughout he body of Between the Acts: "Dispersed we are." The dissemination of Sofya and David from their own private existences into a memorialized ripple in the public sphere becomes part of that refrain. In the metaphor of the soundscape, or sonic texture, Sofya and David join the ripples which began to dissipate their memory from the fist rumblings of The Holocaust in Western society's awareness. Simultaneously, when joined by the private consciousness of the two characters, the ripples from Woolf's text gain a new and powerful resonance: that which carries the reverberations of a single human mind. Here the physical boundaries between Sofya and David also begin to subside within the narrative. Out in the open, as they are led through the camp, the narrative goes through a marked shift from the physical realism of the train compartment in which the smell of human bodies, thirst, lice, and fear of violent death dominate the reader's reception of Sofya and David as physical characters, to an ethereal physical realism. Far from replacing physicality with symbols or figurative descriptive language, the physical boundary between Sofya and David are not undone, but it is trespassed. The boundary between characters and memory is trespassed by the gradual deemphasizing of utilitarian physicality. Instead of forcing Sofya and David's bodies out of representation so that the narrative can assume a more political and atemporal polemic state, Grossman's narrative decontextualizes the narrative of their bodies so that their shoulders, legs, guts, and hearts assume a narrative existence that is uniquely personal as opposed to being the means of production of a genocidal product. The arguments is not that Sofya and David become 
disembodied, but that their physicality becomes one that is only reproducible through the property of sound.

\section{Sofya's Body in its Own Economy of Silence and Music}

In the next phase of the narrative, Sofya as a character, and Grossman's representation of the Holocaust, must enter a different expression of public sphere: the inside of the gas chamber. To narrate Sofya's single, irrevocably particular death while maintaining the perspective that allows the account to speak as an expression of the historical Holocaust in literature, the narrative assumes an extended form of indirect discourse that interweaves Sofya's private mind and Grossman's perspective within a project of soundscape and memory. The narrative shift happens after a treatment of the notion of death within the absurd dialogue with the sphere of the camps:

Death! It had become sociable, quite at home; it called on people without ceremony, ... Death carried on its own everyday manner, and people in theirs.... It was as though people had now understood death, as though it had at last revealed how humdrum it was, how childishly simple. Really it was an easy crossing, just a shallow stream with planks thrown across from one bank — where there was smoke coming out of the wooden huts...

It was a mere five or six steps. That was all. What was there to be afraid of? (543)

It is important to disambiguate the characteristic of the narrative after the reformulation of death in the passage from a mere expression of passivity. Grossman's choice of establishing the matter-of-factness of death as the main component in the dialogue between his characters and their surroundings does not erase the urgency of the narrative. 
As Sofya is walking the short steps toward the chamber, the three elements that dominate the narrative from that point forward can be identified as the musical score of her narrative: the transformation from factual realism of physical violence to an almost dream-like detachment to the physical world, the intermingling of Sofya's (and David's) private thoughts with the narrative voice, and the dialogue with death that pervades the narrative once the characters approach the threshold of the chamber:

[A man] seemed to grow taller and more imposing; with a sudden nimble jump, as though he had spread his wings, he punched an SS guard in the face and knocked him to the ground. Sofya Levinton leapt after him with an angry shout....In the brief instant when Sofya had attempted to attack the guard, she had forgotten about David. Now once more she took him by the hand. David saw how clear, fierce and splendid human eyes can be when - even for a fraction of a second - they sense freedom. By now...their steps sounded different as they marched through the wideopen doors. (546)

Instead of describing the scene in the same hyper-realistic tone from the train compartment scene, the actual punch to the guard's face, Sofya's decision and physical action in joining the attack, the scene is presented as a memory in which the significance of action has replaced the mechanical factuality of the action. Since of the narrative perspective employed, the bodies involved are communicated in excess of the narrative through its soundscape. The extent of Sofya's train of thought is expressed in the same manner. Instead of an in-depth exposition of her intimate decision to attack the guard, and then to pull back To die with David, her thoughts and her action are seen only through 
their effect on David, as if he is listening to the action as notes in a composition. Sofya's complex action of revolt preceding her death becomes a memory of its effect on the moment.

Once the group enters the changing-room, Sofya thinks "It was as though the body of a whole people, previously covered by layers of rags, was laid bare in [the] naked bodies of all ages..." (547). Not only are the bodies revealed as an expression of people and memory that goes beyond the untouchable and irrevocably isolated existence of single bodies of flesh, Sofya's thought also reveals the extent to which Grossman simultaneously surrenders control of the primary narrative voice to Sofya, while maintaining the historical perspective as an archivist of catastrophe. Sofya's thoughts must dominate the narrative as she becomes aware of her naked body within this dialogue with the chamber and with history. Grossman's narrative reaches into the most private thoughts in Sofya's life. In a single thought, Sofya invokes her mother, as a physical mother and as her union to a people, and her own motherhood as an undeniable act of physical aliveness as a woman and as a connection to the future of her people: "Sofya looked at her own broad, white shoulders; no one had ever kissed them—only her mother, ... when she was a child... [She was no] longer ashamed of the maternal feelings that had been aroused in her-virgin though she was..." (547).

Sofya's virginity cannot be read as an allegory for purity, that is far from the tone with which Grossman reveals the detail about her. Her virginity is not a disclosure of Sofya's sexual life, but of her internal life. The thought is of tenderness for her mother, and for the unlikelihood of physical kindness for another as she is about to be killed. 
Motherhood, however, is not a theme to be ignored in the passage. Motherhood is the most extreme form of dialogue between bodies without giving up neither of the bodies' singular existences. Grossman makes use of maternity not as an event, but as an act of transformation and memory representation. The same idea is expressed in a voice that is both Sofya's and the narrative's: that the clipped hair covering the floor made it seem that "the women were washing their legs in streams of bright and dark water" (548). Hair is invoked as the only physical part of the women that will not be turned into ashes, as a physical marker of identity, and as a narrative transformation of togetherness. The women, as metaphorical mothers of an entire people, are united by the black sea of their own surviving body parts as a memory of their destruction.

\section{Fate as Insertion into the Public Sphere: The Web of Humanity in War}

As she is about to cross the threshold into the chamber, Sofya looks into the eyes of the officer standing by the entrance. She had been thinking "If one man is fated to be killed by another, it would be interesting to trace the gradual convergence of their paths.... eventually we are bound to meet, we can't avoid it...' (550). When she sees the guard, she thinks "There he was; they had met at last!" (551). Sofya feels the urge to crush his neck. The man strikes her with his club mid smile. However, neither of the physical movements in narrated as material action. Here the narrative technique chosen by Grossman reaches its climax of material transcendence by soundwaves. The only physical materiality in the narrative is the "ringing of bells and the crunch of broken glass in her head" through which she hears the words “"Easy now, you filthy Yid!'” (551). The 
sound of the bells eviscerates the inescapable materiality of Sofya's death. The bells can ring in excess of her material circumstances well into the diasporic future.

The crushing of Sofya's skull and the sound of broken glass also brings into the realm diasporic memory the material existence of "Kristallnacht." Sofya's reflection on the inevitability of fate act as a juxtaposition between the nearly inescapable web of public policy in its expression as fate, and the individual acceptance of that policy To keep it from dissipating. Sofya's death is simultaneously the result of a mysterious fate much larger than her self and the small action of a pathetic drunk man. Her death is utterly fictional, material, linear, and hopeless in the face of actual history, while it also transports the memory of the actual dead into a tangible expression of musical memory.

\section{Reading the Physicality of Death}

In spite of the soundscape of diasporic memory, the utter physical dejection of the death chamber is also present in Grossman's narrative, and it must be acknowledged as such. Once they enter the chamber, the bodies of the prisoners assume a movement that mirrors that of aimlessly shifting particles. ${ }^{50}$ Grossman, a chemist by training, introduces the comparison many chapters earlier, while tracing the building of the chambers:

\footnotetext{
${ }^{50}$ Rosette Lamont, in one of the few English language reviews of Life and Fate, states the other level of uniqueness of Sofya Levinton's death in literature: “Grossman introduces us to the gas chamber after having allowed us to follow the victims' via dolorosa until the very end ... Grossman remains resolutely sober and truthful. I know of no such scene in Holocaust literature" (48).

To the present, the uniqueness has gone unexpressed in the limited amount of scholarly work on Grossman's narrative in the English language.
} 
Number 1 complex [of chambers] was constructed according to the principle of the turbine. It was capable of transforming life itself, and all forms of energy pertaining to it, into inorganic matter. This new turbine had to overcome and harness the power of psychic, nervous, respiratory, cardiac, muscular and circulatory energy. And in this building the principle of the turbine was combined with those of the slaughter-house and the garbage incineration unit (474).

Once they are inside the chamber, people begin to move aimlessly, finding and losing each other according to the rebellion and hypnotic submission of people's bodies, obeying indiscriminate laws of physics according to their size. However, the aimless movement begins to gain solidity. A mother and daughter lock in an embrace, "fusing into one indivisible body...bodies were touching each other, people's thoughts and feelings fusing together, ..." until, after a disruption in the flow of people, Sofya and David find each other again, and "[Sofya] clasped the boy to her with the peculiar strength familiar to the Germans who worked there- when they emptied the chamber, they never attempted to separate bodies locked in a close embrace" (553). When the door closes, a voice that may be David's or anyone's, thinks "Finally they became one" (553). The solidity and union of people's bodies works as an affront to the inescapability of their fate. Grossman's narrative remains polemic, vengeful even, but it does so without succumbing to the need to make any of the dead unfathomably heroic, or noble.

Once David detects the "faint, rather sweet smell" of Zyklon B (553), Sofya's body becomes once and for all detached from utilitarian function. She does not want to look when David spots a fan crawling into motion, "[h]er eyes — which had read Homer, 
Izvestia, Huckleberry Finn, Mayne Reid,... were no longer of use to her. If someone had blinded her, she would have felt no sense of loss" (553). There is neither silence nor sound to the narrative at this point. There is an absolute absence of soundscape, and yet, the imagery of archival music still offers the best path of analysis for the nearly impenetrable narrative strategy. Sofya's body begins to subside from the narrative until it comes to be archived in the bells—which she hears again—, ringing again in her head (553), forbidding any thought. The bells are the archival sound of memory as it is not Sofya that embodies the bells, but the other way around, at this point. It is through the sound in which her body, with its cracked skull, has been inscribed, that we continue to hear her thoughts after the effects of the gas make her "mute, blind, [with] eyes still open" (554).

Sofya feels David die and then falls after him, “'I've become a mother,' she thought.... That was her last thought" (544). Here it is necessary to look at Grossman's original text To highlight the sublimation of time and the material presence necessary to express a thought of motherhood. ${ }^{51}$ The original Russian states "Я стала матерью." Robert Chandler's translation is irreproachable for most readings of the line. However, the choice of present perfect binds Sofya to the present moment, a fateful choice, as this reading uncovers. In Russian, the grammar allows for Sofya to be simultaneously there in the moment, and simultaneously to become a past-tense mother always-already in diasporic sonic memory. The present tense in the sentence is constructed with a past tense verb "стала," which, by itself means "I was," in the feminine inflection. The original

${ }^{51}$ All subsequent translations of the Russian language are original of this reading. 
grammar establishes the traumatic presence/absence required of diasporic memory. Her body and memory stretch towards the past, as they do toward the future. Sofya exists after death: "Her heart, however, still had life in it: it contracted, ached and felt pity for all of you, both the living and the dead."

The pity Sofya feels, beyond her death, reflects a thought she first had in the traincart chapter as she watches people's faces in silence, she realizes " ... that their heads were filled with painfully vivid images that no words could ever convey. How could these images be preserved, how could they be fixed—in case men remained alive on earth and wanted to find out what had happened?" (200). In the chamber, after her death, the thought becomes pity: a pity that condemns and absolves the living and the dead. In the Russian, where the word "all" is not present or necessary, she pities "вас," "уоu," which can be a plural you, the sense highlighted by Chandler's translation, or it can be a respectful singular "you." The oscillation between a singular and a plural "you" in Sofya's last address to/through the narrative expresses the private and public responsibility in the recovery of the past in diasporic memory. Sofya's narrative does not end at the close of the chapter. It ends somewhere in the future, in the responsibility inherited by the "you" that can listen to the soundscape of memory. Sofya's memory is always "to come." It remains the responsibility of those who remain living to find the literary music with which to listen. 


\section{Bibliography}

Aravamudan, Srinivas. Enlightenment Orientalism: Resisting the Rise of the Novel. Chicago: The University of Chicago Press, 2012. Print.

Aristotle. Nicomachean Ethics. Trans. Terence Irwin. Indianapolis, Ind: Hackett Pub. Co, 1999. Print.

Ashby, Hal. Harold and Maude. Hollywood, California: Paramount Pictures, 2000. DVD.

Bakhtin, Mikhail. The Dialogic Imagination: Four Essays. Austin: University of Texas Press, 1981. Print.

Barlow, Daniel. "Literary Ethnomusicology and the Soundscape of Jean Toomer's Cane." MELUS: Multi-Ethnic Literature of the U.S. Vol. 39, No.1 (2014): pp. 192-211.

Benjamin, Walter. “The Storyteller”. Illuminations. New York: Schocken Books, 1985. Print.

- ."The Work of Art in the Age of Mechanical Reproduction". Illuminations. New York: Schocken Books, 1985. Print.

Bell, Clive. “Art and War.” International Journal of Ethics. Vol. 26, No.1 (Oct., 1915), pp. 1-10. Web. 8 Feb. 2014.

Bottome, Phyllis. The Mortal Storm. Boston: Little, Brown and Company, 1938. Print

Cavarero, Adriana. Horrorism: Naming Contemporary Violence. New York: Columbia University Press, 2009. Print.

Connerton, Paul. How Societies Remember. Cambridge [England: Cambridge University Press, 1989. Print.

Cuddy-Keane, Melba. "The Politics of Comic Modes in Virginia Woolf's Between the Acts". PMLA 105.2 (Mar 1990) pp. 273-285. Print.

Derrida, Jacques, and Eric Prenowitz. Archive Fever: A Freudian Impression. Chicago: University of Chicago Press, 1996, Print.

-. Sovereignties in Question: The Poetics of Paul Celan. New York: Fordham University Press, 2005. Print.

Ellis, Frank. "Vasilii Grossman: The Genesis of Heresy 1937-41." The Modern Language Review. Vol. 85, No. 3 (Jul., 1990), pp. 653-666. Print. 
Evans, Elizabeth. “Air War, Propaganda, and Woolf's Anti-Tyranny Aesthetic." Modern Fiction Studies, V1. 59, No. 1, Spring 2013, pp. 53-82. Print.

Garrard, John G, and Carol Garrard. The Bones of Berdichev: The Life and Fate of Vasily Grossman. New York: Free Press, 1996. Print.

Garrard, John. "Stepsons in the Motherland: The Architectonics of Vasilii Grossman's Zhizn i Sud'ba.” Slavic Review, Vol. 50, No. 2 (Summer, 1991) , pp. 336-346. Print.

Grossman, Vasily. An Armenian Sketchbook. New York: New York Review of Books, 2013. Print.

-. Life and Fate: A Novel. Trans. Robert Chandler.New York: Harper \& Row, 1986. Print.

—-.Zhizn' I Sud'ba: Roman. Moskva: Izd-vo "Knizhnaia palata," 1988. Print.

-. A Writer at War: Vasily Grossman With the Red Army 1941-1945. Ed/Trans. Antony Beevor, Luba Vinogradova. London: Vintage, 2005. Print.

Hertz, Erich, and Jeffrey Roessner. Write in Tune: Contemporary Music in Fiction. New York : Bloomsbury, 2014. Print.

"holocaust, n." OED Online. Oxford University Press, March 2014. Web. 19 March 2014.

Hobsbawm, Eric J.. The Age of Revolution, 1789-1848. , 1962. Print.

Husserl, Edmund. Cartesian Meditations: An Introduction to Phenomenology. The Hague: M. Nijhoff, 1977. Print.

Lehmann, John. Virginia Woolf and Her World. London: Thames and Hudson, 1975. Print.

Levi, Primo. "If This Is a Man" Survival in Auschwitz: The Nazi Assault on Humanity. New York: Collier Books, 1993. Print.

Lubrich, Oliver. Travels in the Reich, 1933-1945: Foreign Authors Report from Germany. Chicago: The University of Chicago Press, 2010. Print.

McWhirter, David. "The Novel, the Play, and the Book: Between the Acts and the Tragicomedy of History. ELH, Vol. 60. No. 3 (Autumn 1993). pp. 787-812. Print.

Morrison, Toni. Beloved: A Novel. New York: Vintage International, 2004. Print. 
Nancy, Jean-Luc. Listening. New York: Fordham University Press, 2007. Print.

Poole, Roger. The Unknown Virginia Woolf. Atlantic Highlands, N.J: Humanities Press International, 1990, Print.

Scanlan, John. "Fragments Of Time And Memory: Matter, Media And The Modern Auditory World." European Journal Of English Studies 15.1 (2011): 19-29. Print

Shakespeare, William, Stephen Greenblatt, Walter Cohen, Jean E. Howard, Katharine E. Maus, and Andrew Gurr. "Hamlet." The Norton Shakespeare. New York: W.W. Norton, 2008. Print.

Smith, Helen Z. Not so Quiet: Stepdaughters of War. New York: Feminist Press at the City University of New York, 1989. Print.

Strebe, Amy G. Flying for Her Country: The American and Soviet Women Military Pilots of World War Ii. Washington, D.C: Potomac Books, 2009. Print.

"troubadour, n." OED Online. Oxford University Press, March 2014. Web. 19 March 2014.

Trouillot, Michel-Rolph. Silencing the Past: Power and the Production of History. Boston, Mass: Beacon Press, 1995. Print.

Wanczyk, David. "So They Fidgeted': The Modernist Twitch of Between the Acts." Woolf Studies Annual. 2011, Vol. 17, p108. Print.

Whittier-Ferguson, John. "Repetition, Remembering, Repetition: Virginia Woolf's Late Fiction and the Return of War." Modern Fiction Studies. Vol. 57, No. 2, Summer 2011,230-253. Print

Winterhalter, Teresa. "'What Else Can I Do But Write?': Discursive Disruption And The Ethics Of Style In Virginia Woolf's Three Guineas." Hypatia: A Journal Of Feminist Philosophy 18.4 (2003): 236-257. Print.

Woloch, Alex. The One Vs. the Many: Minor Characters and the Space of the Protagonist in the Novel. Princeton, N.J: Princeton University Press, 2003. Print.

Wolfe, Cary. What Is Posthumanism?Minneapolis: University of Minnesota Press, 2010. Print.

Woolf, Virginia. Between the Acts. New York: Harcourt Brace Jovanovich, 1969. Print.

-.Collected Essays, Vol. 2. London: Hogarth P, 1966. Print.

-.Collected Essays, Vol. 4. London: Hogarth P, 1966. Print. 
-.."Craftsmanship," BBC Broadcast Words Fail Me. BBC Digital Archives:

Audio. Web. Sept. 7, 2013.

-. The Death of the Moth and Other Essays. New York: Harcourt Brace Jovanovich, 1974. Print.

-.Mrs. Dalloway. New York: Harcourt, Brace and Co, 1925. Print.

-. Moments of Being: Unpublished Autobiographical Writings. London:Chatto and Windus for Sussex University Press, 1976. Print.

- A Room of One's Own. New York and Burlingame: Harcourt, Brace and World, 1957. Print.

-. A Writer's Diary: Being Extracts from the Diary of Virginia Woolf. Ed. Leonard Woolf. New York: Harcourt, Brace, 1954. Print. 